\title{
Aluminous websterite and
}

granulite xenoliths from the Chyulu

Hills volcanic field, Kenya

Gabbro-troctolitic cumulates subjected to lithospheric foundering

\author{
Journal Article \\ Author(s): \\ Ulianov, Alexey; Kalt, Angelika; Pettke, Thomas \\ Publication date: \\ 2006-10 \\ Permanent link: \\ https://doi.org/10.3929/ethz-b-000022463
}

Rights / license:

In Copyright - Non-Commercial Use Permitted

Originally published in:

Contributions to Mineralogy and Petrology 152(4), https://doi.org/10.1007/s00410-006-0114-3 


\title{
Aluminous websterite and granulite xenoliths from the Chyulu Hills volcanic field, Kenya: gabbro-troctolitic cumulates subjected to lithospheric foundering
}

\author{
Alexey Ulianov $\cdot$ Angelika Kalt $\cdot$ Thomas Pettke
}

Received: 20 April 2005/ Accepted: 6 June 2006/Published online: 11 July 2006

(C) Springer-Verlag 2006

\begin{abstract}
Whole rock major and trace element abundances in aluminous garnet-spinel websterite, sapphirine-bearing $\mathrm{Mg}-\mathrm{Al}$ granulite and hibonite-bearing $\mathrm{Ca}-\mathrm{Al}$ granulite xenoliths from the Chyulu Hills volcanic field, Kenya, suggest that the samples represent a metaigneous suite linked by fractionation. The incompatible major element contents increase from the websterites to the $\mathrm{Mg}-\mathrm{Al}$ granulites and further to the $\mathrm{Ca}-\mathrm{Al}$ granulites. High bulk rock Mg\#s and very low concentrations of most incompatible trace elements indicate that the rocks are cumulates rather than crystallized melts. Elevated $\mathrm{Ni}$ abundances, impoverishment in $\mathrm{Cr}$ and HFSE and high contents of normative plagioclase and olivine in the granulites indicate that their protoliths were similar to troctolite. The textures and metamorphic reaction paths recorded in the granulites suggest igneous emplacement in the crust and cooling from igneous to ambient crustal temperatures accompanied or followed by compression. For the websterite xenoliths, there is an apparent contradiction between the results of $P-T$
\end{abstract}

Communicated by J. Hoefs

A. Ulianov $\cdot$ A. Kalt

Geological Institute, University of Neuchâtel,

Rue Emile-Argand 11, 2009 Neuchâtel, Switzerland

T. Pettke

Institute of Geological Sciences, University of Bern,

Baltzerstrasse 1-3, 3012 Bern, Switzerland

Present Address:

A. Ulianov $(\square)$

Institute of Mineralogy and Petrography,

University of Lausanne, BFSH 2,

1015 Lausanne, Switzerland

e-mail: Alexey.Ulianov@unil.ch calculations that suggest high $P$ and $T$ of crystallization of early generation pyroxenes and elevated $P-T$ conditions during final equilibration $\left(1.4-2.2 \mathrm{GPa} / 740-980^{\circ} \mathrm{C}\right)$ on the one hand and the positive Eu anomaly that suggests shallow-level plagioclase accumulation on the other hand. This contradiction can be reconciled by a model of compression of a plagioclase-bearing (gabbroic) protolith to mantle depths where it recrystallized to an ultramafic assemblage, which requires foundering of dense lower crustal material into the mantle.

\section{Introduction}

Mafic-ultramafic rock associations form an important volume of island and continental arc lithosphere. They represent crystallized melts/cumulates formed at deep or shallow levels and provide important insights into the formation of the Earth's crust and the evolution of the continental crust and uppermost mantle (e.g. Conrad and Kay 1984; DeBari et al. 1987; Ducea and Saleeby 1996; Weber et al. 2002; Spandler et al. 2003; Claeson and Meurer 2004; Topuz et al. 2004). Metamorphosed mafic-ultramafic complexes consisting mainly of pyroxenite and granulite are common in the exhumed cores of orogenic belts. There, they may represent either fossil continental crust-to-mantle transitions (e.g. Hermann et al. 2001) or continental arc crust (e.g. Cesare et al. 2002), but often they are indicative of subducted and subsequently exhumed oceanic sequences (e.g. Takazawa et al. 1999; Morishita et al. 2003).

Pyroxenites and granulites also occur in xenolith suites entrained by continental intraplate volcanism (e.g. Kempton et al. 2001; Embey-Isztin et al. 2003; 
Dessai et al. 2004; Sutherland et al. 2004). Some of these pyroxenite-granulite associations have been interpreted as comagmatic crystal fractionation sequences of basaltic liquids, often overprinted by subsolidus thermal relaxation and metamorphism (e.g. Upton et al. 2001; Dessai et al. 2004). These pyroxenites and granulites usually have no genetic relation to the host magmatism and represent ancient lithosphere. Their geochemical study helps to understand the nature of igneous differentiation at depth, while the study of metamorphic overprints they display provides insights into the evolution of the lithosphere at deep levels unaffected by exhumation processes.

This study focuses on a suite of comagmatic aluminous meta-igneous cumulates from the Chyulu Hills volcanic field (eastern flank of the Kenya Rift), located within the Pan-African Mozambique belt. Comagmatic aluminous pyroxenite-granulite xenolith suites are rare but known from several localities on the Arabian plate where tertiary to recent volcanism has sampled the lithosphere of the Mozambique belt. These suites are considered to be of Pan-African age and calc-alkaline affinity (McGuire and Stern 1993; Nasir 1995; AlMishwat and Nasir 2004). On pyroxenite and granulite xenoliths in volcanic edifices situated within the Mozambique belt of East Africa, few data are available. Granulite xenoliths were described from the Lashaine volcano in northern Tanzania (Dawson 1977; Jones et al. 1983). They represent relics of a metamorphosed igneous suite (Jones et al. 1983), but with a different chemical and mineralogical composition compared to the xenoliths from this study.

The xenoliths investigated here include garnet-spinel websterite, two-pyroxene sapphirine-bearing granulite and clinopyroxene hibonite-bearing granulite. Mineralogy and mineral modes indicate that these rocks do not represent cumulates of tertiary to recent alkaline magmatism related to the Kenya Rift. The geochemical and textural features of the websterite xenoliths, along with the complex subsolidus reaction textures of the granulite xenoliths (Ulianov and Kalt 2006) suggest that they may belong to the Pan-African arc lithosphere of the Chyulu Hills thinned by some foundering process such as that described for the southern Sierra Nevada today (e.g. Ducea and Saleeby 1996; Ducea 2001; Zandt et al. 2004).

\section{Geological setting}

The Chyulu Hills volcanic field is located on the eastern flank of the Kenya rift. It lies some 150 $200 \mathrm{~km}$ east of the rift axis and $50 \mathrm{~km}$ northeast of

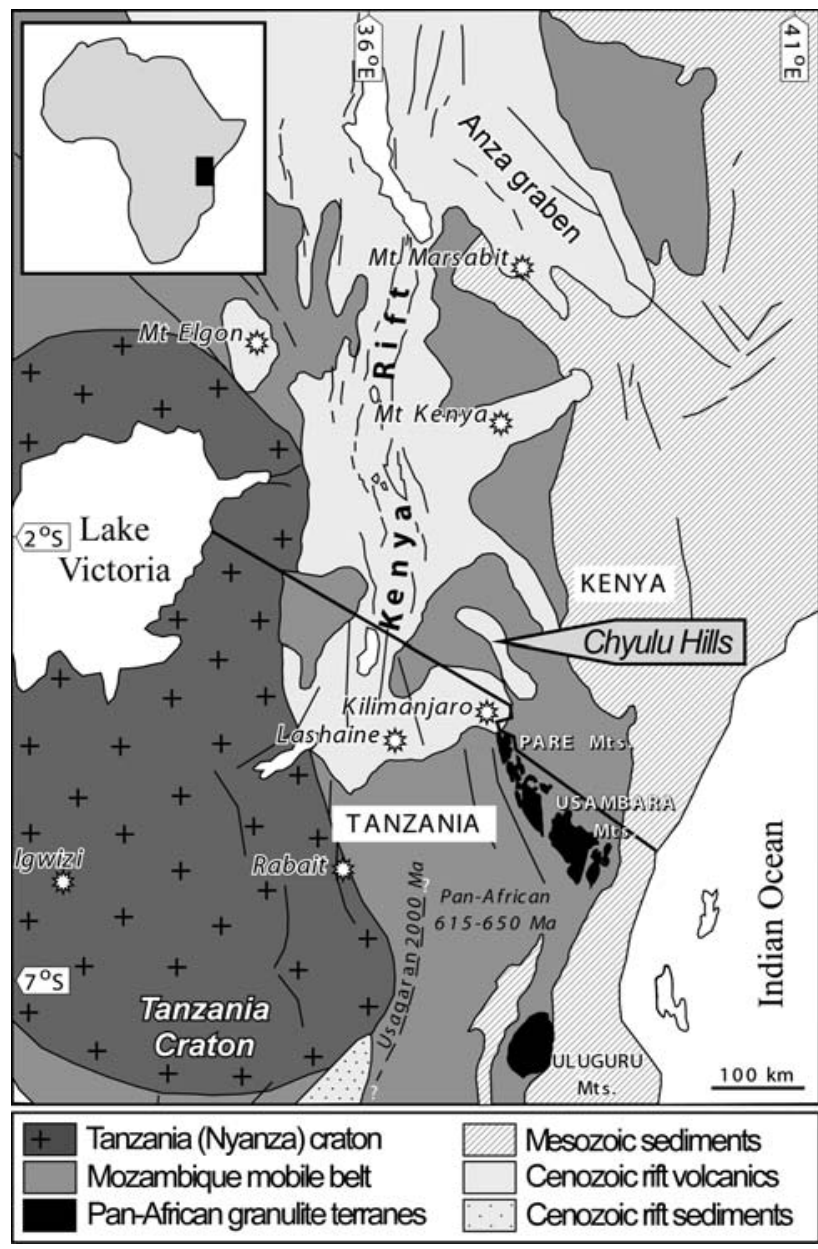

Fig. 1 Simplified geological map of Kenya and northern Tanzania. Shown are principal tectonic units and volcanic areas as well as the location of the Chyulu Hills. The outcropping granulite complexes of NW Tanzania are after Möller et al. (2000), the distribution of Cenozoic volcanic and sedimentary rocks in the region is after Williams (1970) and Baker et al. (1971)

Mt.Kilimanjaro, close to the border with Tanzania (Fig. 1). The Chyulu Hills include several hundred volcanic cones forming a $\sim 100 \mathrm{~km}$ long chain aligned in a NW-SE direction. The Chyulu Hills have been the target of petrological studies on mantle xenoliths (Henjes-Kunst and Altherr 1992; Altherr et al. 2006, submitted) and on alkaline volcanics (Haug and Strecker 1995; Späth et al. 2001) as well as of structural and geophysical studies (Haug and Strecker 1995; Ritter and Kaspar 1997; Novak et al. 1997a, 1997b).

The general structure of the lithosphere beneath the Chyulu Hills has been investigated by a wide-angle reflection and refraction experiment and by seismic tomography. The Moho was detected at a depth of $\sim 44 \mathrm{~km}$, with a thickness of ca. $20 \mathrm{~km}$ assigned to the lower crust (Novak et al. 1997b; Ritter and Kaspar 1997). The lithosphere-asthenosphere boundary was 
not detected seismically. However, porphyroclastic garnet lherzolite and depleted garnet-spinel harzburgite xenoliths from the northwestern Chyulu Hills yield geothermobarometric estimates of $1,300-1,350^{\circ} \mathrm{C}$ and 3.3-3.6 GPa, which suggests a lithospheric thickness of approximately $115 \mathrm{~km}$ (Henjes-Kunst and Altherr 1992; Altherr et al. 2006, submitted).

Volcanism of the Chyulu Hills is of quaternary age. Main types of volcanic rocks include foidite, less silicaundersaturated basanite, and fractionated alkali basalt (Haug and Strecker 1995; Späth et al. 2001). Most upper mantle and lower crustal xenoliths are hosted in basanite. This study is based on xenoliths collected from several volcanic edifices in the northwestern part of the Chyulu Hills. Apart from the Quaternary alkali volcanics, no manifestations of magmatism younger than the Pan-African have yet been found within or around the Chyulu Hills.

The Chyulu Hills lie on the crystalline basement of the Mozambique belt. Main local basement lithologies include amphibolite-facies gneiss, amphibolite and migmatite (Saggerson 1963; Omenge and Okelo 1992). Pyroxenites were not reported and granulites are rare. They are calc-silicate, dominated by andesitic plagioclase, pyroxenes, scapolite, garnet and epidote (Saggerson 1963). Corundum, sapphirine or other Al-rich phases are not mentioned (Saggerson 1963). In local outcrops, no granulites comparable to the specimens investigated in this study have been described.

\section{Analytical techniques}

Major elements in minerals were analyzed using electron microprobes CAMECA SX50 (MineralogischPetrographisches Institut, University of Bern) and CAMECA SX51 (Mineralogisches Institut, University of Heidelberg). Results from these two laboratories are consistent. Both instruments are equipped with wavelength-dispersive spectrometers. Operating conditions for routine analyses included a $15 \mathrm{kV}$ accelerating voltage and a $20 \mathrm{nA}$ beam current. The analyzed area was $\sim 2 \mu \mathrm{m}$ in diameter for mafic phases and $5-10 \mu \mathrm{m}$ for plagioclase. Counting times for most elements were $20 \mathrm{~s}$. Raw spectrometer data were reduced with the PAP program.

To reintegrate the major element compositions of strongly exsolved early generation pyroxenes in the websterite xenoliths, modal proportions of the exsolved garnet were estimated using back-scattered electron images. The bulk compositions of finely exsolved orthopyroxene in the granulite xenoliths were obtained by electron microprobe using a defocused beam.
Trace element abundances in minerals were determined on a LA-ICPMS instrument equipped with a $193 \mathrm{~nm}$ ArF excimer laser (Lambda Physik, Gottingen, Germany) coupled to an ELAN 6100 quadrupole ICP-MS (Perkin-Elmer, Woodbridge, ON, Canada) at the Institut für Isotopengeologie und Mineralische Rohstoffe, ETH Zürich (for capabilities of the instrument and analytical technique, see Günther et al. 1997; Heinrich et al. 2003). Analytical conditions were similar to those reported in Pettke et al. (2004). An SRM 610 external standard from NIST was used. Internal standards were $\mathrm{Ca}^{42}$ (pyroxenes, plagioclase, garnet, and kelyphite after garnet), $\mathrm{Mg}^{25}$ (olivine), and $\mathrm{Al}^{27}$ (spinel). The spot size ranged from 14 to $110 \mu \mathrm{m}$, depending on grain size and on whether core areas or rims of mineral grains were analyzed. For core areas, except for plagioclase with abundant inclusions, a $110 \mu \mathrm{m}$ spot size was used, resulting in lower limits of detection. Raw data were reduced off-line using the LAMTRACE program. For exsolved pyroxene grains, averages from several shots with a $110 \mu \mathrm{m}$ spot size were calculated.

Three sets of analyses of major element concentrations were performed on bulk rock samples. The first two sets were obtained on lithium tetraborate fused disks using XRF spectrometers Philips PW2400 at the Institut für Geologie und Mineralogie, University of Cologne, and at the Institut de Minéralogie et de Pétrographie, University of Fribourg. The third set was made on glass pills (for preparation technique, see Ulianov et al. 2005) using a CAMECA SX50 microprobe at the Mineralogisch-Petrographisches Institut, University of Bern. The beam was rastered over an area of ca. $15 \times 20 \mu \mathrm{m}$ and operating conditions were the same as for minerals. The three sets of measurements are in good agreement with each other, with no systematic deviations for specific elements. At the same time, most of the XRF analyses are characterized by somewhat low totals (9899 wt.\%), which seems to be concerned with an incomplete decomposition of highly refractory phases (corundum and aluminous spinel, which are rockforming minerals in the studied specimens) during smelting. On the contrary, the glass pills proved to be homogeneous and yielded better totals. Henceforth, we will, therefore, use the microprobe data obtained on glass pills. Whole-rock trace element abundances were measured on glass pills using the same LA-ICPMS technique as for minerals. A spot size of $110 \mu \mathrm{m}$ was used. $\mathrm{Cr}, \mathrm{Ni}, \mathrm{Co}, \mathrm{Sr}$, and $\mathrm{Ba}$ were also determined by XRF at the University of Fribourg, together with major elements. 


\section{Petrography, major element composition of minerals and $P-T$ evolution}

Each of the studied rock groups, garnet-spinel websterite, $\mathrm{Mg}-\mathrm{Al}$ sapphirine-bearing granulite and $\mathrm{Ca}-\mathrm{Al}$ hibonite-bearing granulite, consists of petrographically similar rocks. The grain size ranges from 2 to $4 \mathrm{~mm}$ (early generation pyroxenes, plagioclase) to $0.1-$ $0.2 \mathrm{~mm}$ (sapphirine, hibonite, spinel in granulite xenoliths). Some xenoliths are banded and consist of layers of more mafic and more felsic lithologies. The mineral assemblage of the different layers is the same. As no foliation or other indications of metamorphic differentiation processes is observed, the banding seems igneous in origin. Although xenoliths of the same group appear petrographically similar, no lithologies intermediate between the groups were found. Textures of the xenoliths are shown in Figs. 2, 3, and 4. Representative mineral compositions are given in Tables 1,2 , and 3. $P-T$ calculations for the websterite xenoliths are summarized in Table 4. A more comprehensive discussion on textures and $P-T$ conditions for the granulite xenoliths is given in Ulianov and Kalt (2006).

All studied xenoliths show pronounced subsolidus re-equilibration. Their igneous mineral assemblages are either completely replaced or obliterated. The xenoliths are also modified by late-stage heating and decompression in the host basanites. Garnet is usually replaced by kelyphite; only rare relicts are preserved. Clinopyroxene is often decomposed into micro-aggregates of secondary diopside, plagioclase and quenched melt. Numerous microprobe profiles performed for all minerals in all samples enable us, however, to distinguish these effects from primary major element variations (Altherr et al. 2006, submitted; Ulianov and Kalt 2006). In the following, we will refer to non-modified compositions only (see Tables 1-3).

\section{Garnet-spinel olivine websterite xenoliths}

These xenoliths (1910-1, 1910-11, 1535-3, and 1906-4) are composed of ortho- and clinopyroxene (20-25\% each), garnet (40-45\%), as well as subordinate olivine and spinel ( $<10 \%$ each). One xenolith (1906-4) consists of two websteritic parts separated by a thin vein of potassium feldspar with frequent needle-like inclusions of corundum. Textures and mineral assemblages of the websterite xenoliths are shown in Fig. 2a-c.

The earliest mineral assemblage consists of large anhedral clinopyroxene (cpx Ia) and orthopyroxene (opx Ia) grains often containing garnet inclusions
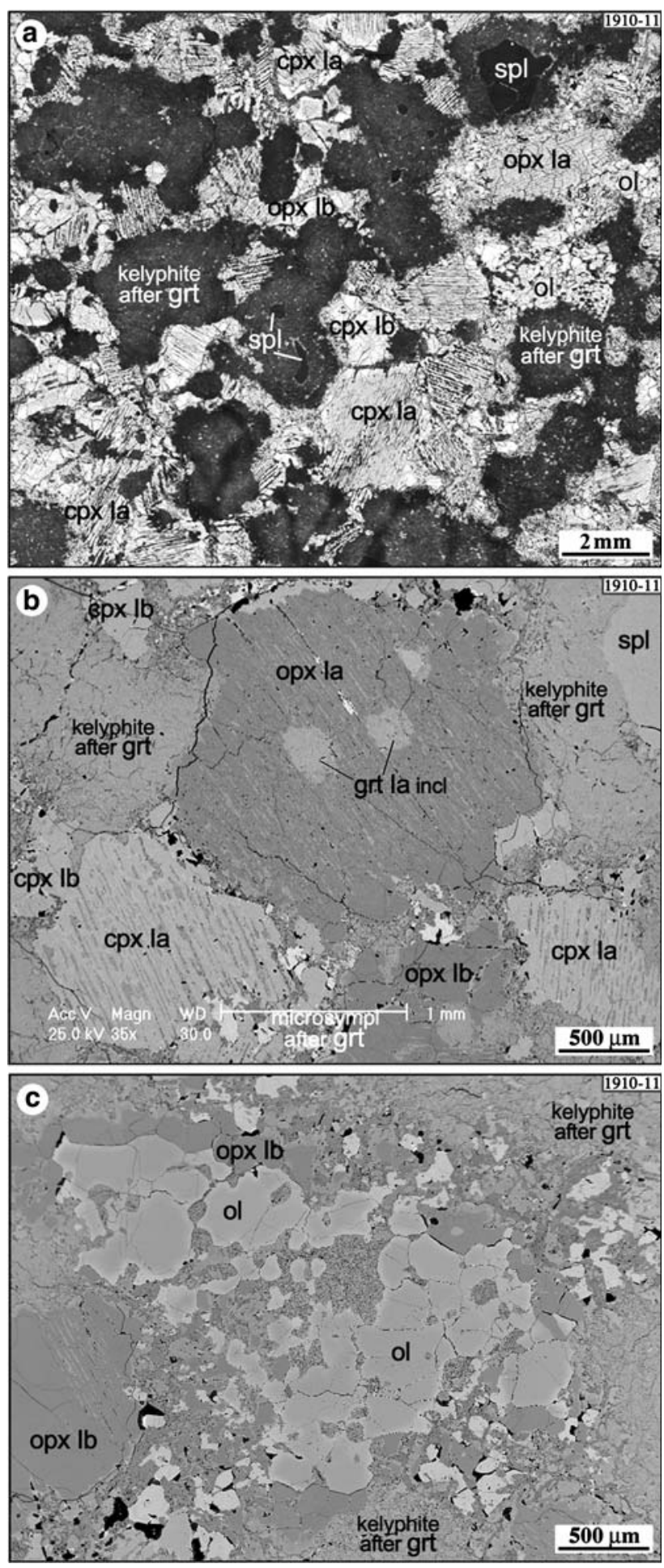

Fig. 2 Plane polarized photomicrograph (a) and back-scattered electron images $(\mathbf{b}, \mathbf{c})$ showing textures and different generations of the major mineral phases in garnet spinel websterite xenoliths. a General texture defined by pyroxenes Ia, garnet and spinel. b Early generation clinopyroxene Ia and orthopyroxene Ia with garnet inclusions in the core part. c Olivine and its relationships with garnet and orthopyroxene. Mineral abbreviations are after Kretz (1983) 

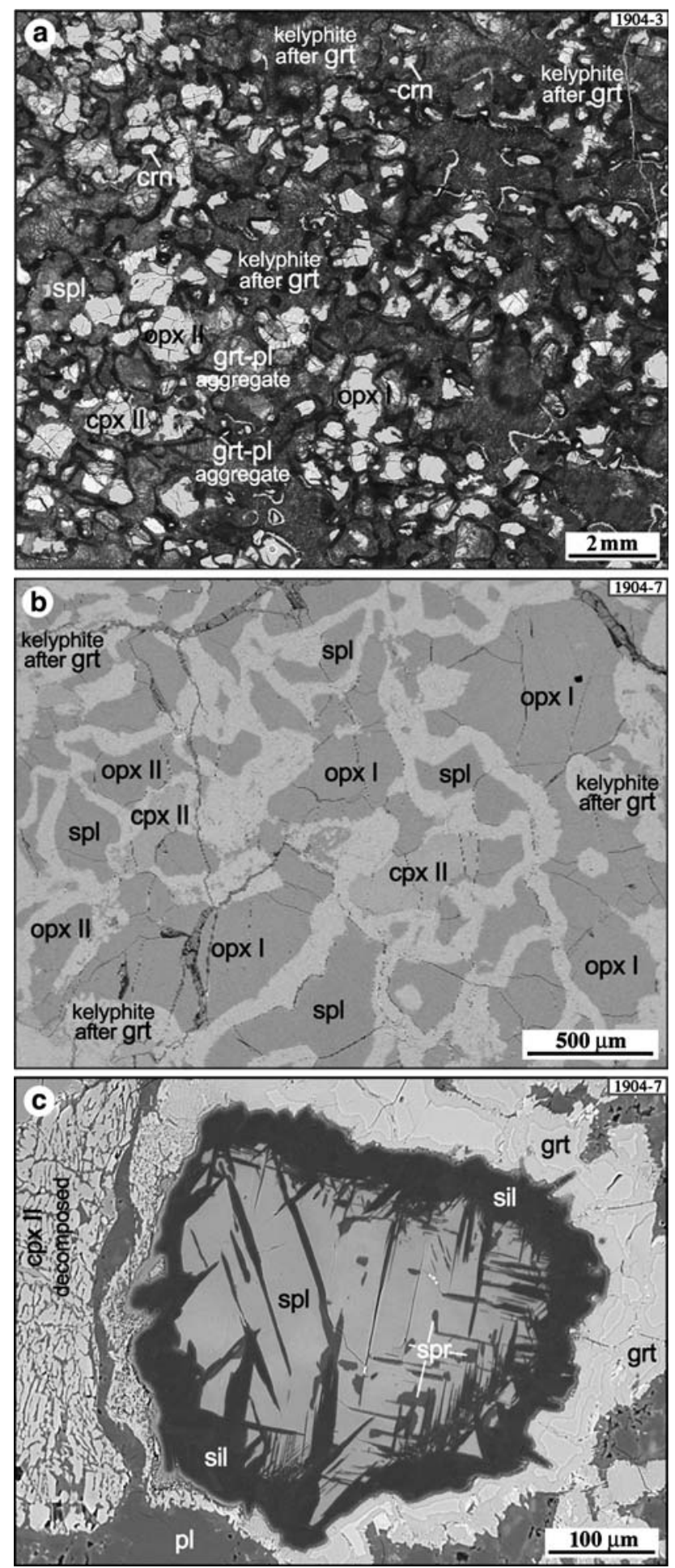

Fig. 3 Plane polarized photomicrograph (a) and back-scattered electron images $(\mathbf{b}, \mathbf{c})$ illustrating textures and different generations of the major mineral phases in $\mathrm{Mg}-\mathrm{Al}$ sapphirine-bearing granulites. a General texture defined by pyroxene, corundum and garnet. b Coarse-grained symplectite aggregates of orthopyroxene, clinopyroxene and spinel. c Sapphirine, sillimanite, and garnet replacing spinel. Mineral abbreviations are after Kretz (1983)
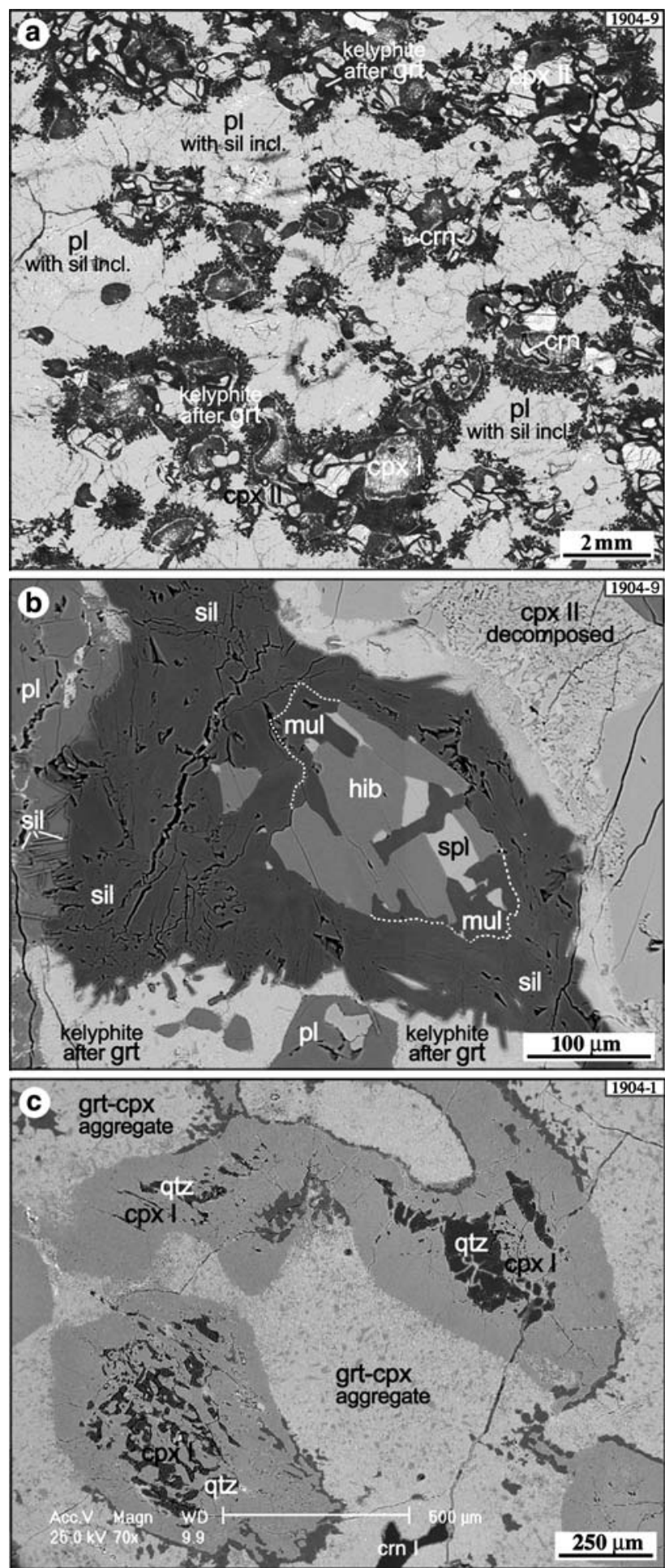

Fig. 4 Plane polarized photomicrograph (a) and back-scattered electron images $(\mathbf{b}, \mathbf{c})$ illustrating textures and different generations of the major mineral phases in $\mathrm{Ca}-\mathrm{Al}$ hibonite-bearing granulites. a General texture defined by clinopyroxene and plagioclase. b Aggregate of hibonite, spinel, mullite, and sillimanite partially resorbed by garnet. $\mathbf{c}$ Large complex grains of clinopyroxene with quartz in the inner parts. Mineral abbreviations for rock-forming minerals are after Kretz (1983), hib hibonite, mul mullite 


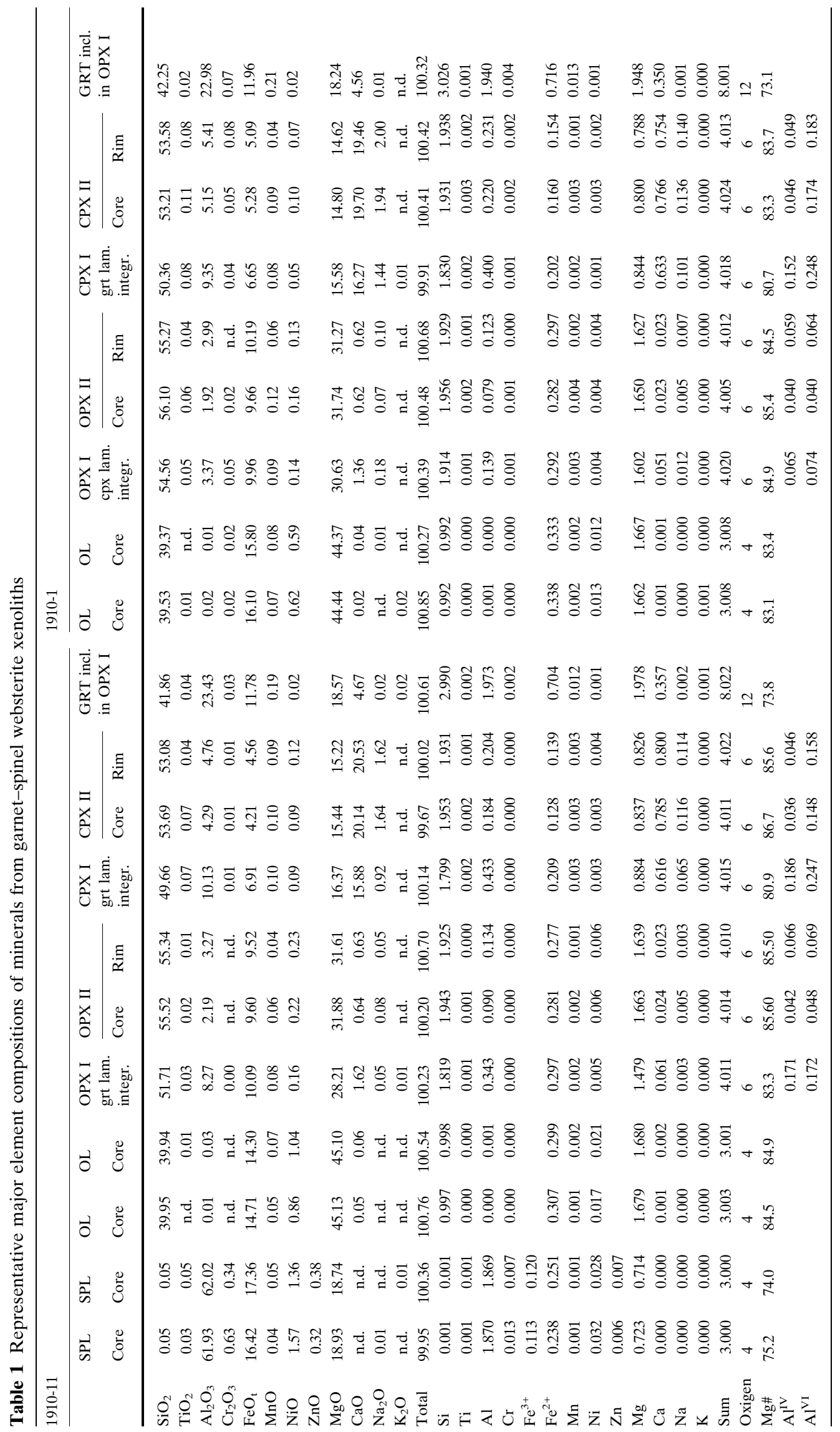




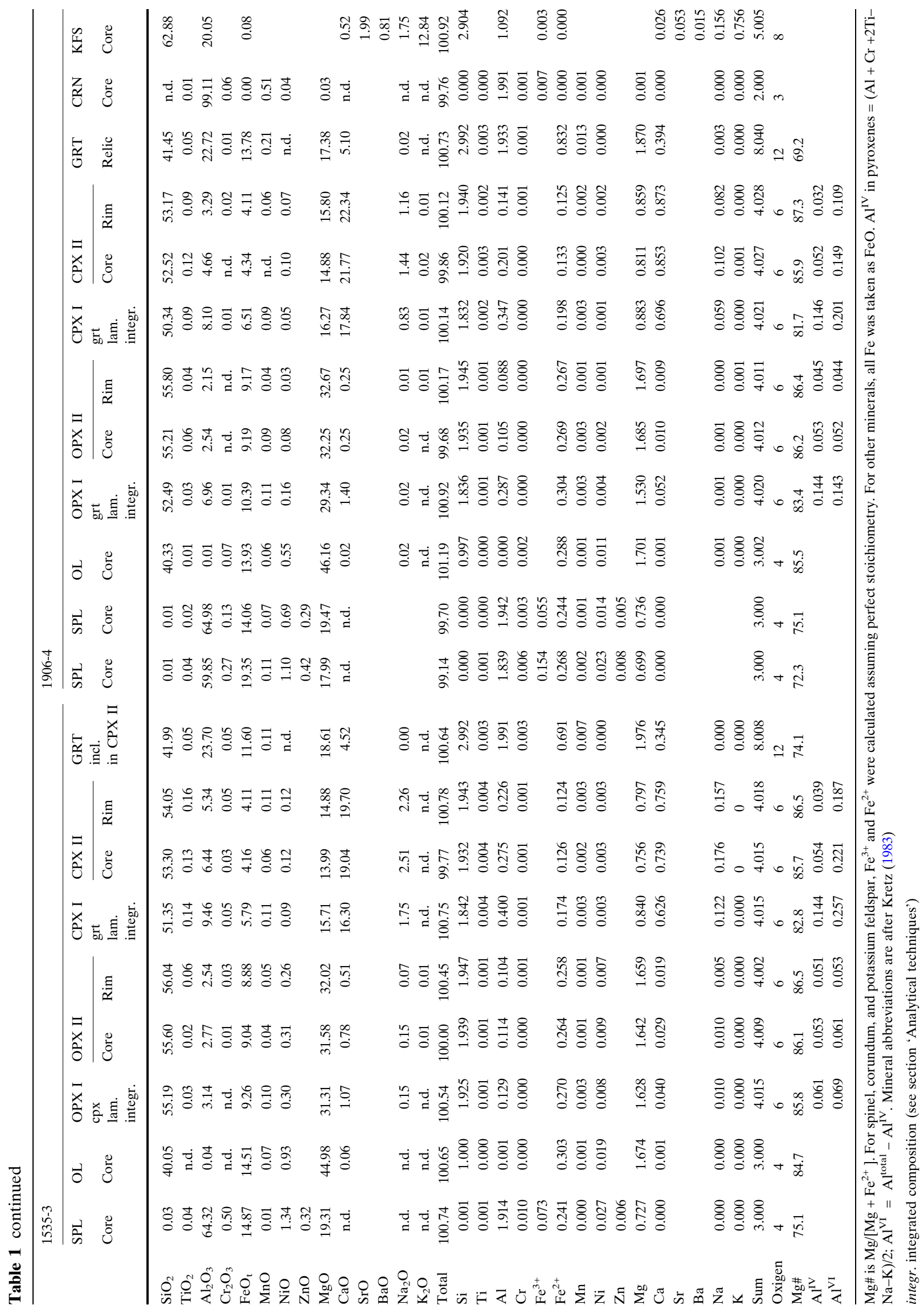




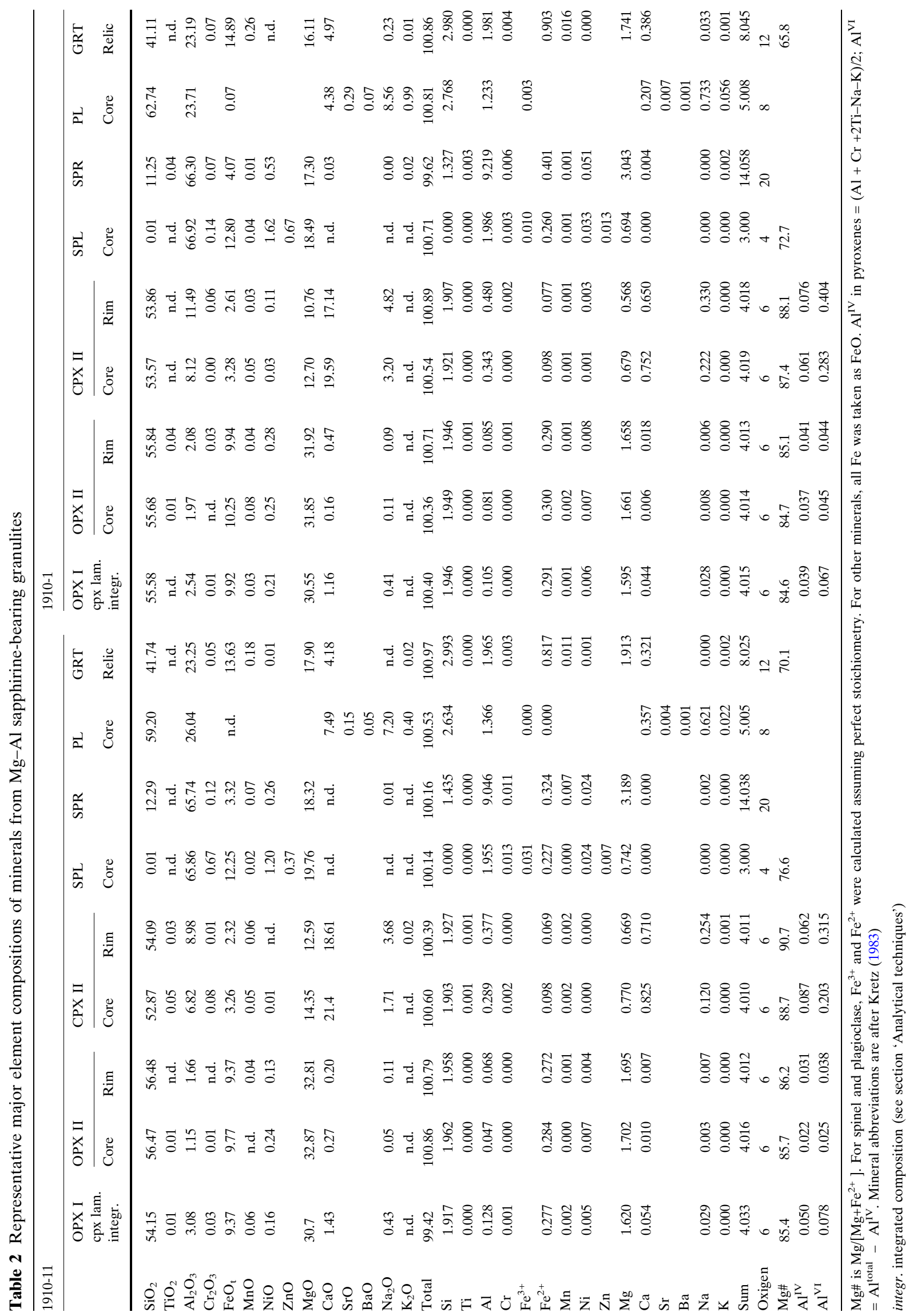




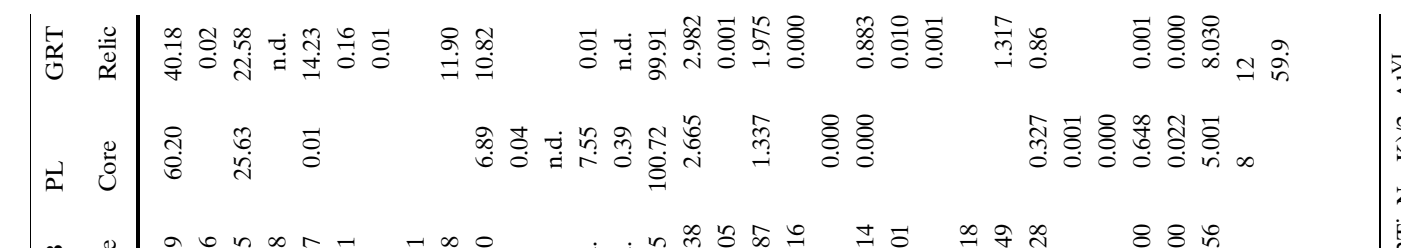

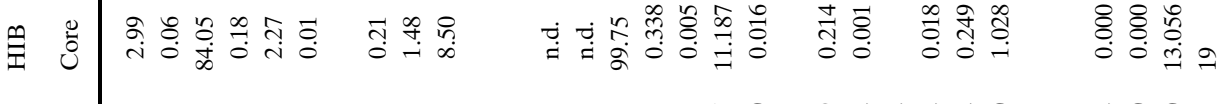

ش

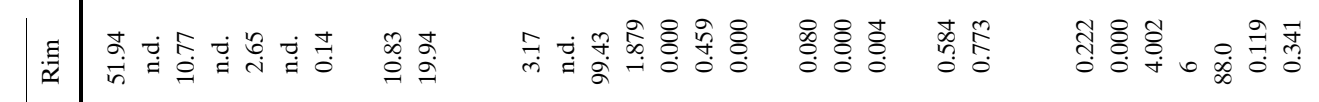

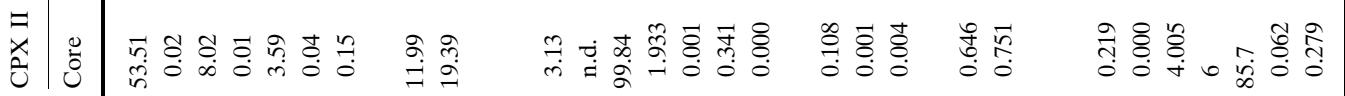

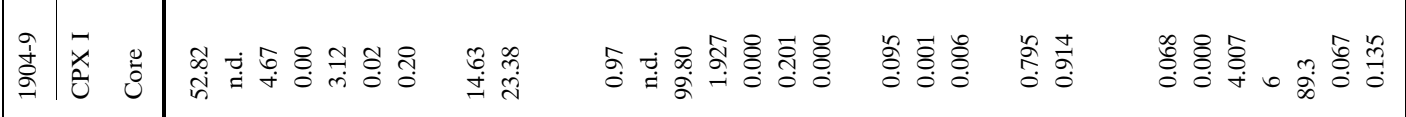

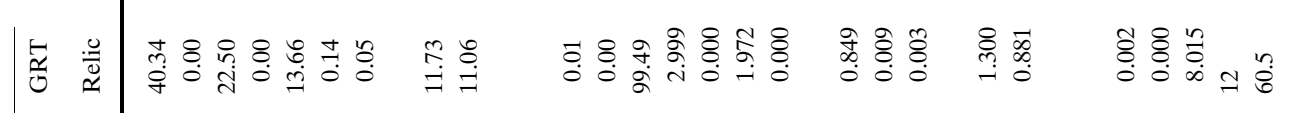

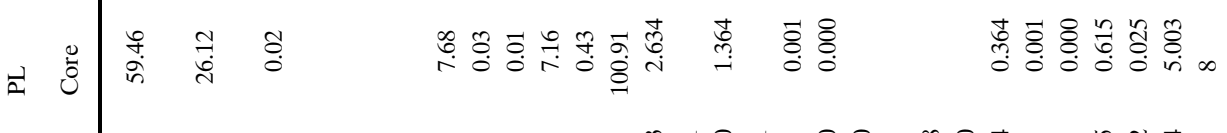

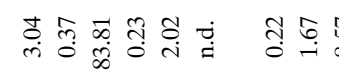

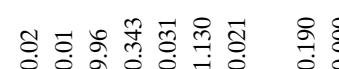

\&.

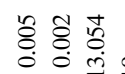

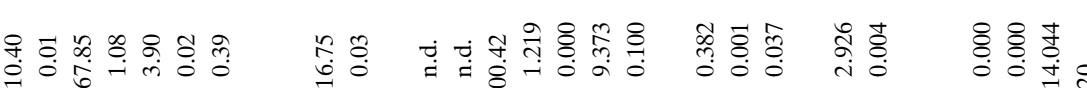

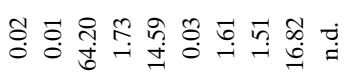

过

\section{(1)}

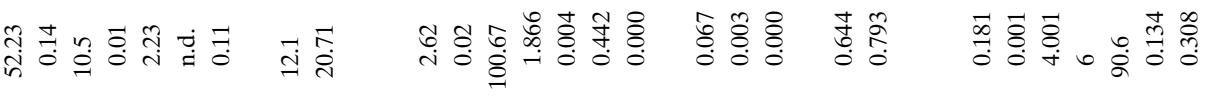

芴

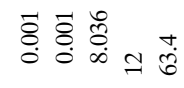

त్ํํㅇํㅇ

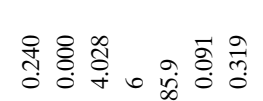

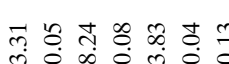


Table $4 P-T$ estimates for garnet-spinel olivine websterite xenoliths

\begin{tabular}{|c|c|c|c|c|c|c|c|c|}
\hline & $1910-11$ & $1 \sigma$ & $1910-1$ & $1 \sigma$ & $1535-3$ & $1 \sigma$ & $1906-4$ & $1 \sigma$ \\
\hline \multicolumn{9}{|l|}{ Reintegrated core composition of $p x I a$} \\
\hline$T$ two-px solvus (Brey and Köhler 1990) & 1,234 & & & & & & 1,161 & \\
\hline$P$ Al-in-opx (Brey et al. 1986) & 1.96 & & & & & & $1.37^{a}$ & \\
\hline T Ca-in-opx (Brey and Köhler 1990) & 1,224 & & 1,170 & & 1,109 & & 1,144 & \\
\hline$P$ Al-in-opx (Brey et al. 1986) & 1.96 & & $1.99^{a}$ & & 2.16 & & $1.37^{a}$ & \\
\hline \multicolumn{9}{|l|}{ Rim compositions of px Ia } \\
\hline$T$ two-px solvus (Brey and Köhler 1990) & 947 & 29 & 961 & 36 & 948 & 18 & 735 & 36 \\
\hline$P$ grt-opx (Brey and Köhler 1990) & 1.82 & 0.05 & 1.99 & 0.08 & 2.16 & 0.03 & 1.37 & 0.07 \\
\hline$T$ two-px solvus (Wells 1977) & 932 & 27 & 936 & 26 & 917 & 21 & 841 & 33 \\
\hline$P$ grt-opx (Brey and Köhler 1990) & 1,369 & 0.04 & 1.88 & 0.07 & 2.01 & 0.04 & 1.82 & 0.06 \\
\hline T Ca-in-opx solvus (Brey and Köhler 1990) & 959 & 29 & 975 & 32 & 927 & 22 & 778 & 38 \\
\hline$P$ grt-opx (Brey and Köhler 1990) & 1.88 & 0.05 & 2.04 & 0.09 & 2.07 & 0.05 & 1.54 & 0.08 \\
\hline
\end{tabular}

$P$ in GPa, $T$ in ${ }^{\circ} \mathrm{C}$. Standard deviations $(1 \sigma)$ are given in parentheses. Values obtained from Fe/Mg garnet-pyroxene thermometers are not quoted because of possible modification of the garnet $\mathrm{Fe} / \mathrm{Mg}$ ratios by kelyphitization

${ }^{a} P$ fixed according to estimates from two-pyroxene solvus thermometer-garnet-orthopyroxene barometer of Brey and Köhler (1990) for Rim compositions of pyroxene grains, since the pyroxenes may have undergone some escape of Al in intersticies during postmagmatic cooling

(grt Ia), and large individual grains and aggregates of spinel (Fig. 2a, b). Pyroxenes Ia bear exsolution lamellae of garnet (grt $\mathrm{Ib}$ ) in their cores and are resorbed by garnet in the rim parts. Reintegrated core compositions of opx Ia are rich in $\mathrm{Al}$ and $\mathrm{Ca}$ as compared to rims and to a younger generation of smaller, more euhedral opx grains that usually lack exsolved garnet (opx Ib, Table 1). Reintegrated core compositions of cpx Ia are rich in $\mathrm{Mg}$ and $\mathrm{Al}$ and poor in $\mathrm{Ca}$ as compared to rims and to a younger generation of cpx grains (cpx Ib, Table 1), the latter being morphologically similar to opx Ib. Textures and zoning patterns are interpreted to reflect cooling from very high, near igneous temperatures, with pyroxenes continuously crystallizing and adjusting their compositions. Estimates that may approximate peak or early cooling temperatures, based on reintegrated opx Ia core compositions and the presence of garnet, reach $1,230^{\circ} \mathrm{C} /$ 2.0 GPa (Table 4). Partial reequilibration after cooling is calculated to have taken place at $930-980^{\circ} \mathrm{C} / 1.7-$ $2.2 \mathrm{GPa}$, using px Ia rim and px Ib compositions for three samples (1535-3, 1910-1, and 1910-11) and at conditions of approximately $740-840^{\circ} \mathrm{C} / 1.4-1.8 \mathrm{GPa}$ for sample 1906-4 (Table 4). In two of the websterite xenoliths (1910-1 and 1910-11), the outermost pyroxene rims record a young heating event related to rift magmatism (Altherr et al. 2006, submitted).

Garnet (grt Ib) forms a continuous network around pyroxene and spinel grains as well as exsolution lamellae in pyroxenes and intergrowth with olivine (Fig. 2a-c). It is characterized by low $\mathrm{Cr}$ abundances and moderate $\mathrm{Ca}$ contents (Table 1). Spinel is relatively homogeneous, very rich in $\mathrm{Al}$ (up to $65 \mathrm{wt} . \%$ ) and enriched in $\mathrm{Ni}$ and $\mathrm{Zn}$ (Table 1). Olivine shows moderate Mg\#s (83.1-85.5) and very high Ni contents (Table 1). Texturally, both, network garnet and olivine are interpreted to have formed in the course of cooling by partial or complete replacement of spinel and pyroxenes.

$\mathrm{Mg}-\mathrm{Al}$ sapphirine-bearing granulite xenoliths

Xenoliths of this type (1904-3 and 1904-7) consist of ortho- and clinopyroxene (20-30\% each), plagioclase $(7-25 \%)$, garnet $(\sim 20 \%)$, corundum, spinel, and sillimanite (5-7\% each), as well as accessory sapphirine (Fig. 3a-c).

Large orthopyroxene grains with abundant exsolution lamellae of clinopyroxene (opx I) represent hightemperature relicts. Usually, they are surrounded by smaller grains of opx II and cpx II without exsolution textures that form coarse-grained worm-like intergrowths with spinel (Fig. 3b) interpreted to result from the reaction olivine + plagioclase $=$ clinopyroxene + orthopyroxene + spinel (Ulianov and Kalt 2006). Opx I analyzed with a defocused beam shows a pronounced rimward decrease in $\mathrm{Ca}$ and $\mathrm{Al}$. Opx II is less calcic and more homogeneous (Table 2). Cpx II shows an $\mathrm{Al}$ plateau in the core and a rimward increase in $\mathrm{Al}$ content and Mg\#s (Table 2). Corundum is closely associated with pyroxenes and spinel and seems to have formed together with these minerals at the expense of 
the assemblage olivine + plagioclase. Plagioclase (19043: $\left.\mathrm{An}_{21-16} ; 1904-7: \mathrm{An}_{40-30}\right)$ occurs as large grains and polycrystalline aggregates and contains abundant inclusions of sillimanite. Spinel forms individual grains and core parts of complex corona textures that include sapphirine, sillimanite and garnet (Fig. 3c). The sapphirine-, sillimanite-bearing corona textures are developed in textural domains adjoining to plagioclase grains. They are absent in 'ultramafic' pyroxenedominated domains devoid of plagioclase. Spinel is aluminous, relatively rich in $\mathrm{Ni}$ and $\mathrm{Zn}$ (Table 2). Sapphirine is also somewhat enriched in $\mathrm{Ni}$ (up to 0.5 wt.\% NiO). Garnet forms a more or less continuous network around corona structures and individual grains of pyroxenes, spinel, corundum and plagioclase (Fig. 3a-c). Similar to garnet from websterite xenoliths, it demonstrates very low $\mathrm{Cr}$ contents and limited variations in $\mathrm{Ca}$ (Table 2).

Metamorphic reaction textures in the $\mathrm{Mg}-\mathrm{Al}$ granulites point to cooling accompanied or followed by compression (Ulianov and Kalt 2006). Pressure calculations are hampered by the lack of quartz that would allow us to use the qtz-pl-cpx-grt equilibrium. For the exsolved cores of opx I analyzed with a defocused beam, we obtained estimates of 1090 and $1,135^{\circ} \mathrm{C}$ (Brey and Köhler 1990) that may approximate early cooling. For the last stage of equilibration, the estimates range widely from 514 to $784^{\circ} \mathrm{C}$ depending on the geothermometer used (Brey and Köhler 1990; Wells 1977; Harley 1984; Ai 1994; Krogh Ravna 2000).

\section{$\mathrm{Ca}-\mathrm{Al}$ hibonite-bearing granulite xenoliths}

Xenoliths of this type (1904-1, 1904-9, and 1906-2) consist of abundant plagioclase $(40-50 \%)$ and clinopyroxene $(25-30 \%)$, subordianate corundum, sillimanite and garnet $(\sim 5-10 \%$ each), minor spinel and quartz, and accessory mullite and hibonite (Fig. 4a-c).

The earliest mineral assemblages seem to be hibonite accompanied by spinel, mullite, sapphirine, and sillimanite, forming complex corona structures, and clinopyroxene (cpx I) intergrown with quartz in the cores of large complex clinopyroxene grains (Fig. 4a-c). Hibonite, $\mathrm{Ca}\left(\mathrm{Al}, \mathrm{Cr} \text {, Ti, } \mathrm{Si}, \mathrm{Mg}, \mathrm{Fe}^{2+}\right)_{12} \mathrm{O}_{19}$, represents an oxide mineral of the magnetoplumbite group that is rarely found in terrestrial rocks. It may be intergrown with spinel and sapphirine and is partially replaced by mullite and sillimanite (Fig. 4b). Hibonite is rich in $\mathrm{Ca}$ and strongly depleted in REE (Tables 3, 5). A more detailed discussion concerning the petrography and chemical composition of hibonite from the studied xenoliths is given in Ulianov et al. (2005) and Ulianov and Kalt (2006).
The cpx-qtz intergrowths in the core parts of large clinopyroxene grains usually include several large and 10-20 small quartz grains with different optical orientations (Fig. 4c), although large monomineralic quartz cores almost devoid of clinopyroxene can also be found. The cores are mantled by an outer zone of clinopyroxene that lacks quartz and is similar in composition to isolated smaller grains also devoid of quartz (cpx II). Cpx I is less aluminous, more magnesian and calcic than Cpx II (Table 3). Cpx II is zoned and demonstrates a core plateau in $\mathrm{Al}$ and a rimward increase in $\mathrm{Al}$ content and $\mathrm{Mg \#}$ (Table 3). Plagioclase (1904-1: $\mathrm{An}_{39-34}$; 1904-9: $\mathrm{An}_{35-32}$; 1906-2: $\mathrm{An}_{31-26}$ ) forms large grains and polycrystalline aggregates. Corundum grains are closely associated with cpx II. Garnet forms network textures at the expense of all other minerals except hibonite and does not form independent grains. It has fairly high $\mathrm{Ca}$ contents (Table 3 ).

Metamorphic reaction textures in the $\mathrm{Ca}-\mathrm{Al}$ granulites are interpreted to reflect cooling accompanied or followed by compression (Ulianov and Kalt 2006). Quartz never shows direct contact with garnet and plagioclase, thus excluding calculations using the qtzpl-cpx-grt equilibrium. Temperatures obtained with the $\mathrm{Fe}-\mathrm{Mg}$ garnet-clinopyroxene geothermometers (Ai 1994; Krogh Ravna 2000) are $635-639^{\circ} \mathrm{C}$ for specimen $1904-1$ and $725-741^{\circ} \mathrm{C}$ for specimens $1904-9$ and 1906-2. Given the presence of sillimanite in all granulite xenoliths, we fixed a maximum pressure for all temperature calculations at $0.8 \mathrm{Gpa}$.

\section{Trace elements in minerals}

The results of trace-element analyses by LA-ICPMS are given in Table 5. In agreement with the microprobe measurements (Tables 1,2,3), all silicate minerals in both websteritic and granulitic lithologies show extremely low abundances of $\mathrm{Ti}$ and $\mathrm{Cr}$ and elevated contents of Ni. Spinel is also strongly depleted in $\mathrm{Ti}$ and, in most cases, has low $\mathrm{Cr}$ contents. It may contain some $\mathrm{Pb}$ and $\mathrm{Nb}$. Spinel and olivine are important hosts of $\mathrm{Ni}$, Co and $\mathrm{Zn}$ but play no significant role in the LILE, HFSE, and REE budget.

In silicates, strong fractionation of LILE over HFSE and REE is observed, with $\mathrm{Sr}$ and Ba being particularly enriched (Table 5). Sr is hosted preferentially by plagioclase (and clinopyroxene). Clinopyroxene from xenoliths depleted in plagioclase (granulite 1904-3) or devoid of plagioclase (websterites 1910-11 and 1535-3) is very rich in $\mathrm{Sr}$ (up to $250 \mu \mathrm{g} / \mathrm{g}$ ), whereas clinopyroxene from plagioclase-rich granulite xenoliths shows only moderate enrichment in $\mathrm{Sr}(<90 \mu \mathrm{g} / \mathrm{g})$ that 
Table 5 Trace-element analyses (in $\mu \mathrm{g} / \mathrm{g}$ ) of minerals from the studied websterite and granulite xenoliths

Websterite 1910-11

\begin{tabular}{|c|c|c|c|c|c|c|c|c|c|c|c|c|}
\hline \multirow{2}{*}{\multicolumn{2}{|c|}{$\begin{array}{l}\text { SPL I } \\
\text { Core }\end{array}$}} & \multirow{2}{*}{$\begin{array}{l}\mathrm{OL} \\
\text { Core }\end{array}$} & \multicolumn{2}{|l|}{ OPX I } & \multicolumn{2}{|l|}{ OPX II } & \multicolumn{2}{|l|}{ CPX I } & \multirow{2}{*}{$\begin{array}{l}\text { CPX II } \\
\text { Small } \\
\text { grain }\end{array}$} & \multirow{2}{*}{$\begin{array}{l}\text { GRT } \\
\text { Relic }\end{array}$} & \multirow{2}{*}{\multicolumn{2}{|c|}{ Kelyphites }} \\
\hline & & & Core, reint. & Rim & Core & Rim & Core, reint. & Rim & & & & \\
\hline $\mathrm{Li}$ & 1.4 & 1.9 & 1.1 & 0.30 & 0.87 & 0.42 & 0.40 & 0.52 & 1.1 & $<1.16$ & 1.0 & 0.47 \\
\hline $\mathrm{K}$ & $<1.5$ & $<0.70$ & 97 & $<0.53$ & $<0.40$ & 0.68 & 60 & 2.3 & 4.3 & $<14.9$ & 7.4 & 232 \\
\hline $\mathrm{Ti}$ & 162 & 7.5 & 141 & 121 & 122 & 125 & 333 & 408 & 390 & 139 & 153 & 633 \\
\hline $\mathrm{Cr}$ & 1,851 & 5.0 & 68 & 48 & 46 & 49 & 119 & 119 & 91 & 184 & 205 & 115 \\
\hline $\mathrm{Ni}$ & 11,814 & 7,164 & 1,322 & 1,735 & 1,440 & 1,526 & 585 & 762 & 755 & 110 & 90 & 232 \\
\hline $\mathrm{Co}$ & 598 & 340 & 123 & 134 & 120 & 122 & 58 & 49 & 48 & 122 & 96 & 90 \\
\hline $\mathrm{Zn}$ & 3,137 & 161 & 93 & 112 & 92 & 98 & 23 & 25 & 27 & 38 & 28 & 37 \\
\hline V & 107 & 0.81 & 18 & 19 & 16 & 18 & 50 & 63 & 57 & 15 & 15 & 24 \\
\hline $\mathrm{Sc}$ & 0.18 & 0.53 & 3.3 & 0.75 & 0.75 & 0.75 & 4.7 & 2.1 & 2.8 & 13 & 11 & 7.1 \\
\hline $\mathrm{Rb}$ & $<0.023$ & $<0.013$ & 0.13 & $<0.010$ & $<0.011$ & $<0.018$ & 0.077 & $<0.025$ & $<0.014$ & $<0.40$ & $<0.051$ & 0.29 \\
\hline $\mathrm{Sr}$ & 0.034 & $<0.010$ & 4.2 & 0.21 & 1.3 & 0.23 & 114 & 145 & 138 & $<0.25$ & 0.24 & 35 \\
\hline $\mathrm{Y}$ & $<0.018$ & $<0.008$ & 0.30 & $<0.013$ & 0.005 & $<0.011$ & 0.42 & 0.065 & 0.064 & 1.1 & 1.2 & 0.86 \\
\hline $\mathrm{Zr}$ & 0.063 & $<0.030$ & 1.1 & 0.081 & 0.063 & 0.070 & 2.0 & 1.8 & 1.9 & 1.5 & 1.5 & 4.8 \\
\hline $\mathrm{Nb}$ & 0.045 & $<0.013$ & 0.18 & 0.017 & 0.018 & $<0.015$ & 0.25 & 0.23 & 0.18 & 0.19 & 0.048 & 0.54 \\
\hline Cs & $<0.014$ & $<0.007$ & 0.005 & $<0.008$ & $<0.006$ & $<0.008$ & 0.004 & $<0.014$ & $<0.007$ & $<0.27$ & $<0.011$ & $<0.004$ \\
\hline $\mathrm{Ba}$ & $<0.059$ & $<0.053$ & 217 & 0.315 & 0.048 & 0.872 & 203 & 0.28 & 29 & $<1.11$ & 0.28 & 127 \\
\hline $\mathrm{La}$ & $<0.013$ & $<0.007$ & 0.18 & $<0.007$ & 0.014 & 0.011 & 1.24 & 1.6 & 1.6 & $<0.22$ & 0.018 & 0.62 \\
\hline $\mathrm{Ce}$ & $<0.017$ & $<0.005$ & 0.139 & 0.014 & 0.025 & 0.016 & 2.36 & 3.0 & 2.9 & $<0.16$ & 0.083 & 1.0 \\
\hline $\operatorname{Pr}$ & $<0.006$ & $<0.007$ & 0.018 & $<0.005$ & $<0.002$ & $<0.005$ & 0.25 & 0.26 & 0.32 & $<0.12$ & 0.020 & 0.12 \\
\hline $\mathrm{Nd}$ & $<0.037$ & $<0.044$ & 0.11 & $<0.029$ & $<0.010$ & $<0.018$ & 0.93 & 1.4 & 1.3 & 0.78 & 0.14 & 0.53 \\
\hline $\mathrm{Sm}$ & $<0.060$ & $<0.027$ & 0.040 & $<0.019$ & $<0.011$ & $<0.029$ & 0.15 & 0.13 & 0.17 & $<0.46$ & 0.18 & 0.14 \\
\hline $\mathrm{Eu}$ & 0.020 & $<0.012$ & 0.048 & 0.007 & $<0.005$ & $<0.012$ & 0.14 & 0.19 & 0.16 & 0.31 & 0.14 & 0.15 \\
\hline $\mathrm{Gd}$ & $<0.085$ & $<0.034$ & 0.036 & $<0.020$ & $<0.012$ & $<0.021$ & 0.061 & 0.14 & 0.043 & $<0.93$ & 0.22 & 0.13 \\
\hline $\mathrm{Tb}$ & $<0.013$ & $<0.005$ & 0.006 & $<0.004$ & $<0.003$ & $<0.005$ & 0.011 & $<0.008$ & 0.009 & $<0.13$ & 0.014 & 0.029 \\
\hline Dy & $<0.037$ & $<0.021$ & 0.042 & $<0.012$ & 0.011 & $<0.018$ & 0.070 & $<0.022$ & $<0.025$ & $<0.56$ & 0.18 & 0.14 \\
\hline Ho & $<0.012$ & $<0.006$ & 0.012 & $<0.003$ & $<0.002$ & $<0.008$ & 0.020 & $<0.008$ & $<0.005$ & 0.12 & 0.070 & 0.033 \\
\hline $\mathrm{Er}$ & $<0.019$ & $<0.023$ & 0.034 & $<0.015$ & $<0.007$ & $<0.022$ & 0.033 & $<0.045$ & $<0.008$ & $<0.21$ & 0.14 & 0.14 \\
\hline $\mathrm{Tm}$ & $<0.006$ & $<0.005$ & 0.005 & $<0.004$ & $<0.003$ & $<0.003$ & 0.008 & $<0.008$ & $<0.003$ & $<0.069$ & $<0.019$ & 0.009 \\
\hline $\mathrm{Yb}$ & $<0.043$ & $<0.038$ & 0.038 & $<0.028$ & $<0.020$ & $<0.021$ & 0.088 & $<0.051$ & $<0.032$ & $<0.47$ & $<0.13$ & 0.073 \\
\hline $\mathrm{Lu}$ & $<0.018$ & $<0.004$ & $<0.003$ & $<0.003$ & $<0.002$ & $<0.005$ & 0.009 & $<0.011$ & $<0.005$ & $<0.10$ & 0.039 & 0.016 \\
\hline Hf & $<0.065$ & 0.019 & 0.019 & 0.015 & 0.014 & $<0.013$ & 0.085 & 0.059 & 0.085 & $<0.70$ & 0.054 & 0.061 \\
\hline $\mathrm{Ta}$ & $<0.008$ & $<0.006$ & 0.005 & $<0.007$ & $<0.002$ & $<0.004$ & 0.014 & 0.013 & $<0.009$ & $<0.18$ & $<0.022$ & 0.029 \\
\hline $\mathrm{Pb}$ & 0.078 & 0.080 & 0.078 & 0.050 & 0.041 & 0.046 & 0.12 & 0.072 & 0.12 & $<0.56$ & $<0.072$ & 0.12 \\
\hline Th & $<0.007$ & $<0.003$ & 0.045 & 0.004 & 0.023 & $<0.005$ & 0.18 & 0.21 & 0.20 & $<0.11$ & $<0.015$ & 0.059 \\
\hline $\mathrm{U}$ & $<0.007$ & $<0.007$ & 0.029 & 0.009 & 0.005 & $<0.003$ & 0.049 & 0.059 & 0.047 & $<0.10$ & $<0.023$ & 0.023 \\
\hline
\end{tabular}

Websterite 1535-3

\begin{tabular}{|c|c|c|c|c|c|c|c|c|c|c|c|c|}
\hline & \multirow{2}{*}{$\begin{array}{l}\text { SPL I } \\
\text { Core }\end{array}$} & \multirow{2}{*}{$\begin{array}{l}\text { OL } \\
\text { Core }\end{array}$} & \multicolumn{2}{|l|}{ OPX I } & \multicolumn{2}{|l|}{ OPX II } & \multirow{2}{*}{$\begin{array}{l}\text { CPX I } \\
\text { Core, reint. }\end{array}$} & \multicolumn{2}{|l|}{ CPX II } & \multirow{2}{*}{$\begin{array}{l}\text { CPX II } \\
\text { Small } \\
\text { grain }\end{array}$} & \multirow{2}{*}{$\begin{array}{l}\text { GRT } \\
\text { Relic }\end{array}$} & \multirow[t]{2}{*}{ Kelyphite } \\
\hline & & & Core, reint. & Rim & Core & Rim & & Core & Rim & & & \\
\hline $\mathrm{Li}$ & 1.9 & 3.9 & 2.0 & 0.9 & 2.0 & 1.3 & 1.0 & 1.6 & 2.1 & 3.0 & $<0.23$ & 0.16 \\
\hline $\mathrm{K}$ & $<1.4$ & $<1.3$ & $<0.36$ & $<0.52$ & $<0.28$ & 2.1 & 89 & 5.4 & 10.6 & 9.7 & $<2.0$ & $<0.62$ \\
\hline $\mathrm{Ti}$ & 194 & 5.3 & 158 & 129 & 126 & 128 & 475 & 809 & 836 & 514 & 165 & 151 \\
\hline $\mathrm{Cr}$ & 3,832 & $<3.1$ & 124 & 83 & 74 & 79 & 199 & 223 & 253 & 249 & 200 & 199 \\
\hline $\mathrm{Ni}$ & 12,397 & 7,634 & 2,054 & 1,523 & 1,669 & 1,518 & 778 & 783 & 871 & 759 & 96 & 92 \\
\hline $\mathrm{Co}$ & 575 & 333 & 127 & 96 & 107 & 98 & 40 & 38 & 42 & 41 & 108 & 98 \\
\hline $\mathrm{Zn}$ & 3,478 & 158 & 88 & 67 & 79 & 71 & 17 & 19 & 21 & 20 & 23 & 21 \\
\hline $\mathrm{V}$ & 127 & 0.92 & 24 & 19 & 20 & 19 & 67 & 64 & 94 & 88 & 21 & 19 \\
\hline $\mathrm{Sc}$ & $<0.172$ & 0.358 & 0.770 & 0.525 & 0.658 & 0.559 & 2.886 & 2.883 & 3.233 & 2.658 & 14.101 & 14.162 \\
\hline $\mathrm{Rb}$ & $<0.044$ & 0.020 & $<0.006$ & $<0.017$ & $<0.005$ & 0.010 & 0.40 & $<0.007$ & $<0.020$ & $<0.009$ & $<0.036$ & $<0.023$ \\
\hline $\mathrm{Sr}$ & $<0.034$ & 0.10 & 0.26 & 0.16 & 0.20 & 0.22 & 184 & 218 & 229 & 241 & 0.16 & 0.16 \\
\hline $\mathrm{Y}$ & $<0.030$ & $<0.009$ & 0.008 & $<0.007$ & 0.006 & $<0.008$ & 0.35 & 0.16 & 0.16 & 0.12 & 1.3 & 1.2 \\
\hline
\end{tabular}


Table 5 continued

Websterite 1535-3

\begin{tabular}{|c|c|c|c|c|c|c|c|c|c|c|c|c|}
\hline & \multirow{2}{*}{$\begin{array}{l}\text { SPL I } \\
\text { Core }\end{array}$} & \multirow{2}{*}{$\begin{array}{l}\text { OL } \\
\text { Core }\end{array}$} & \multicolumn{2}{|l|}{ OPX I } & \multicolumn{2}{|l|}{ OPX II } & \multirow{2}{*}{$\begin{array}{l}\text { CPX I } \\
\text { Core, reint. }\end{array}$} & \multicolumn{2}{|l|}{ CPX II } & \multirow{2}{*}{$\begin{array}{l}\text { CPX II } \\
\text { Small } \\
\text { grain }\end{array}$} & \multirow{2}{*}{$\begin{array}{l}\text { GRT } \\
\text { Relic }\end{array}$} & \multirow[t]{2}{*}{ Kelyphite } \\
\hline & & & Core, reint. & Rim & Core & Rim & & Core & Rim & & & \\
\hline $\mathrm{Zr}$ & $<0.039$ & 0.051 & 0.18 & 0.11 & 0.13 & 0.16 & 4.2 & 6.1 & 8.3 & 3.5 & 1.1 & 1.4 \\
\hline $\mathrm{Nb}$ & $<0.028$ & $<0.012$ & 0.017 & 0.014 & $<0.006$ & $<0.012$ & 0.55 & 0.80 & 0.65 & 0.76 & 0.073 & 0.070 \\
\hline Cs & $<0.014$ & $<0.014$ & $<0.005$ & $<0.006$ & $<0.002$ & $<0.005$ & 0.004 & $<0.004$ & $<0.012$ & 0.003 & $<0.015$ & $<0.007$ \\
\hline $\mathrm{Ba}$ & $<0.17$ & $<0.051$ & $<0.017$ & $<0.024$ & $<0.014$ & 0.047 & 1.3 & 0.029 & $<0.11$ & 0.094 & $<0.093$ & $<0.030$ \\
\hline $\mathrm{La}$ & 0.019 & 0.020 & 0.006 & $<0.006$ & $<0.004$ & $<0.006$ & 3.3 & 4.7 & 4.7 & 4.7 & 0.028 & 0.009 \\
\hline $\mathrm{Ce}$ & $<0.026$ & 0.012 & 0.024 & 0.007 & 0.015 & 0.028 & 10.4 & 13.6 & 13.8 & 13.4 & 0.14 & 0.21 \\
\hline $\operatorname{Pr}$ & $<0.014$ & $<0.008$ & 0.004 & 0.007 & 0.003 & 0.006 & 1.4 & 1.8 & 1.7 & 1.7 & 0.057 & 0.086 \\
\hline $\mathrm{Nd}$ & $<0.10$ & $<0.032$ & 0.019 & 0.030 & 0.029 & 0.020 & 6.4 & 7.3 & 7.4 & 7.2 & 0.78 & 0.75 \\
\hline $\mathrm{Sm}$ & $<0.049$ & $<0.051$ & $<0.020$ & $<0.029$ & 0.014 & $<0.025$ & 0.82 & 0.83 & 0.90 & 0.87 & 0.29 & 0.31 \\
\hline $\mathrm{Eu}$ & 0.049 & $<0.011$ & $<0.005$ & $<0.005$ & $<0.003$ & $<0.004$ & 0.37 & 0.35 & 0.38 & 0.36 & 0.24 & 0.38 \\
\hline $\mathrm{Gd}$ & 0.055 & $<0.073$ & $<0.017$ & $<0.017$ & $<0.014$ & $<0.015$ & 0.25 & 0.34 & 0.22 & 0.24 & 0.34 & 0.35 \\
\hline $\mathrm{Tb}$ & $<0.011$ & $<0.008$ & $<0.003$ & $<0.003$ & $<0.002$ & $<0.003$ & 0.026 & 0.024 & 0.025 & 0.016 & 0.060 & 0.05 \\
\hline Dy & $<0.044$ & $<0.032$ & $<0.011$ & $<0.011$ & $<0.009$ & $<0.016$ & 0.11 & 0.083 & 0.052 & 0.078 & 0.25 & 0.26 \\
\hline Ho & $<0.008$ & $<0.008$ & $<0.002$ & $<0.003$ & $<0.002$ & $<0.002$ & 0.017 & 0.009 & 0.011 & 0.004 & 0.045 & 0.062 \\
\hline Er & $<0.032$ & $<0.028$ & $<0.005$ & $<0.011$ & $<0.006$ & $<0.010$ & 0.022 & 0.007 & $<0.017$ & $<0.011$ & 0.17 & 0.15 \\
\hline $\mathrm{Tm}$ & $<0.013$ & $<0.005$ & $<0.002$ & $<0.004$ & $<0.002$ & 0.003 & 0.003 & $<0.002$ & $<0.006$ & $<0.003$ & 0.021 & 0.022 \\
\hline $\mathrm{Yb}$ & $<0.087$ & $<0.037$ & $<0.012$ & $<0.017$ & $<0.010$ & $<0.021$ & 0.015 & $<0.014$ & $<0.056$ & $<0.027$ & $<0.147$ & 0.17 \\
\hline
\end{tabular}

Mg-Al two-pyroxene granulite 1904-7

Mg-Al two-pyroxene granulite 1904-3

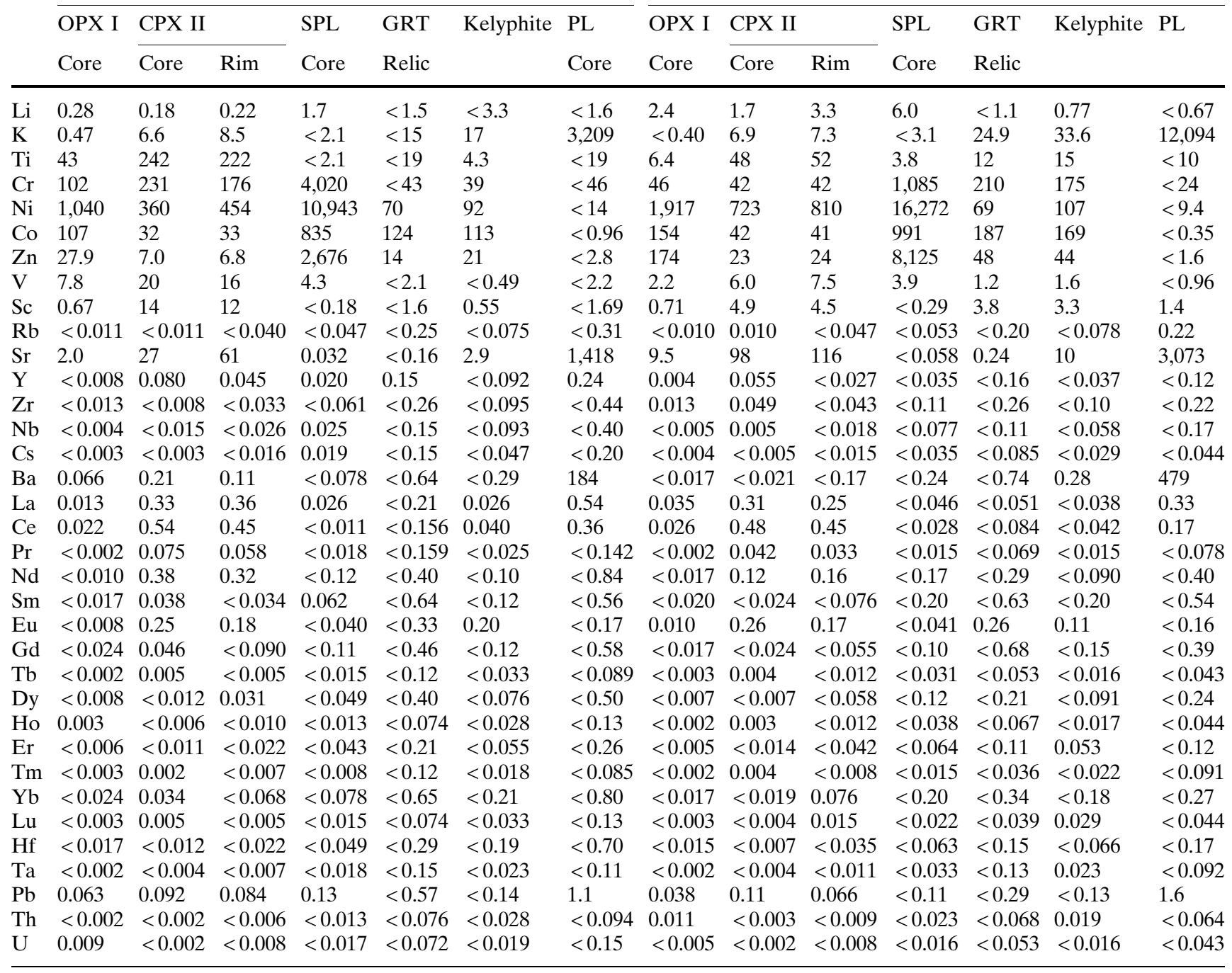


Table 5 continued

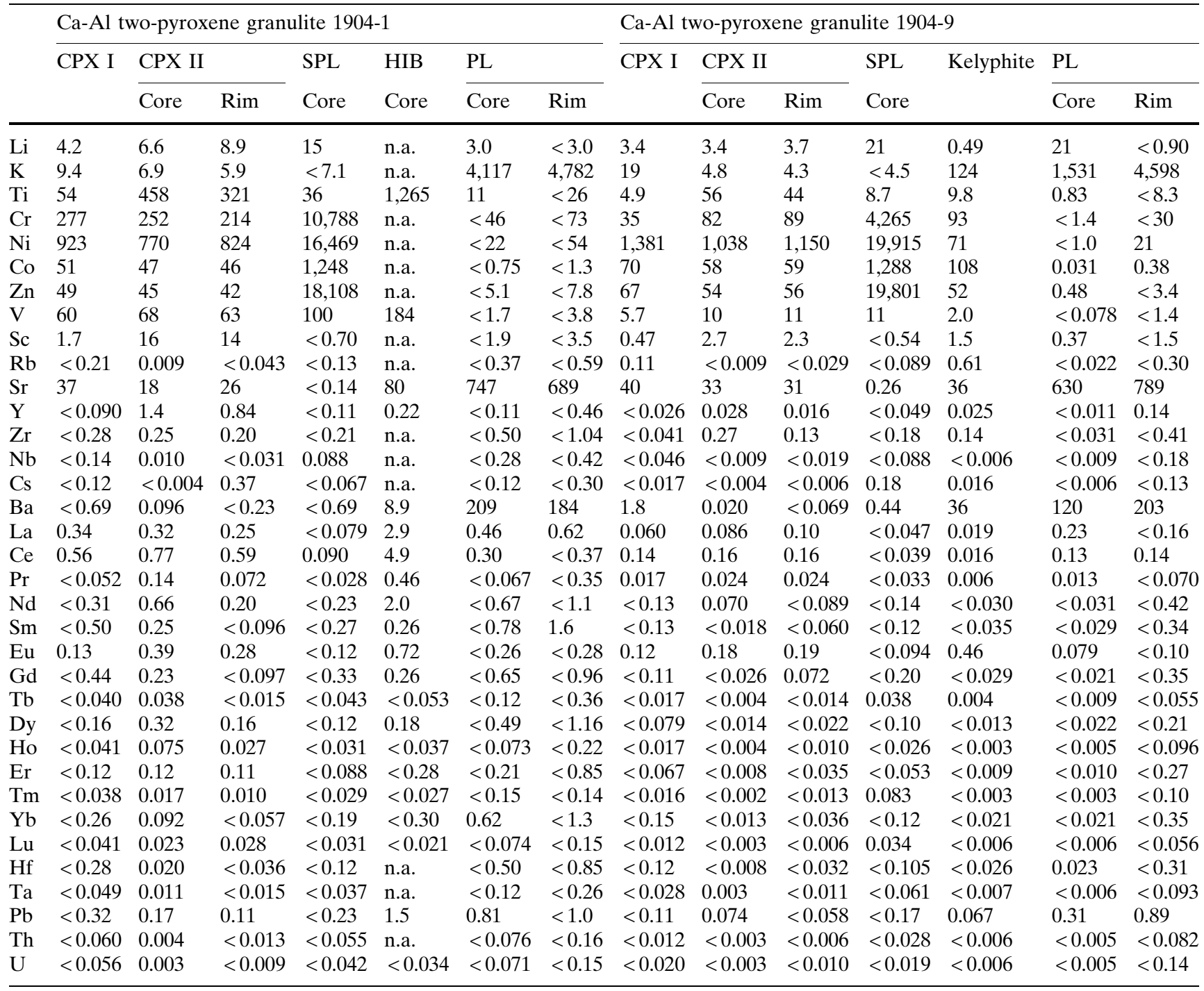

$<$ values represent analyses below the limit of detection

n.a. not analyzed

accumulates in plagioclase (up to $3,000 \mu \mathrm{g} / \mathrm{g}$ ). Plagioclase is also the major carrier of $\mathrm{K}$ and $\mathrm{Ba}$ $\left(\mathrm{K}_{2} \mathrm{O}<1.5\right.$ wt. \%, Ba $\left.<480 \mu \mathrm{g} / \mathrm{g}\right)$.

The HFSE abundances are generally very low. Their major host mineral is clinopyroxene $(\mathrm{Zr}<8.3 \mu \mathrm{g} / \mathrm{g}$ and $<1 \mu \mathrm{g} / \mathrm{g}, \mathrm{Nb}<0.8 \mu \mathrm{g} / \mathrm{g}$, and $<0.04 \mu \mathrm{g} / \mathrm{g}$ in websteritic and granulitic clinopyroxene, respectively). REE abundances are also low, with clinopyroxene and garnet being their major hosts (Table 5). Websteritic clinopyroxene shows a considerable fractionation of LREE over HREE (Fig. 5a). In granulitic clinopyroxene, the REE patterns are less fractionated (Fig. 5b) or nearly flat (sp. 1904-9, Fig. 5c). Positive Eu anomalies are weak in websteritic clinopyroxene and accentuated in granulitic clinopyroxene. In the granulite xenoliths, plagioclase also accounts for a considerable fraction of the bulk rock REE content as well as for the fractionation of LREE over HREE (Table 5).

Websteritic clinopyroxene shows elevated abundances of most incompatible elements compared to clinopyroxene from granulites (Fig. 6a-c). Both websterite- and granulite-hosted clinopyroxene show negative anomalies of $\mathrm{Nb}, \mathrm{Zr}$, and $\mathrm{Hf}$ and enrichment in $\mathrm{Sr}$ and Eu. No significant difference in trace element abundances is found, neither between different generations of clinopyroxene nor between core and rim zones of clinopyroxene grains with clear major element zonation (see Table 5, Figs. 5, 6). For websteritic pyroxenes I with abundant exsolution lamellae of garnet (kelyphitized), reintegrated compositions (see section 

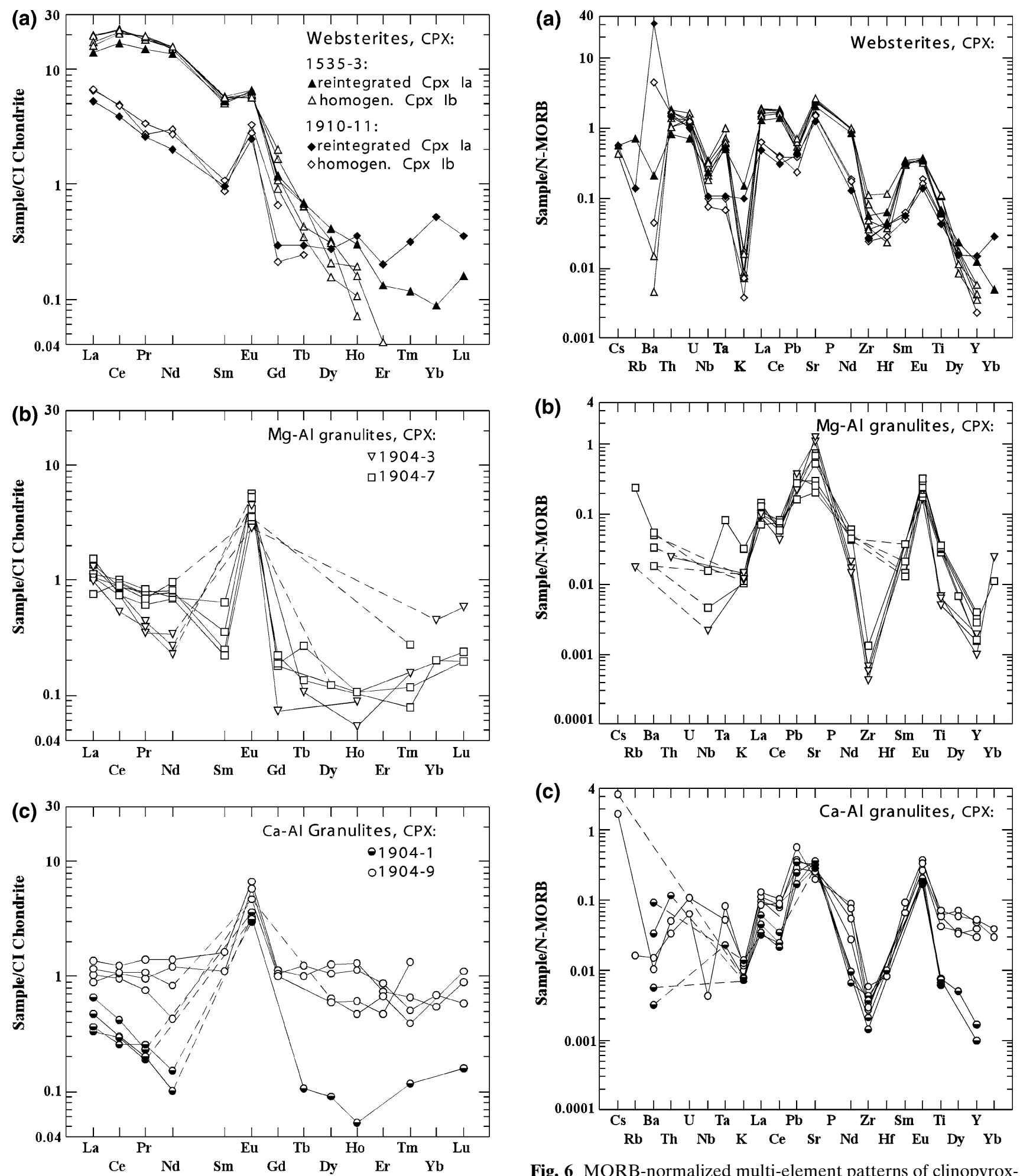

Fig. 5 Chondrite-normalized rare earth element patterns of clinopyroxene and garnet from the studied xenoliths. Normalization values are from Sun and McDonough (1989)

'Analytical techniques') are generally similar to those of homogeneous clinopyroxene II (Figs. 5a, 6a). Exceptions are HREE, $\mathrm{Ba}$, and $\mathrm{K}$ (higher than in cpx II).

Fig. 6 MORB-normalized multi-element patterns of clinopyroxene from the studied xenoliths. Normalization values are from Sun and McDonough (1989). Symbols as in Fig. 5

Only one relict of unaltered interstitial garnet (from websterite 1535-3) was large enough to be analyzed by LA-ICPMS. Its REE pattern (Fig. 7) is characterized 


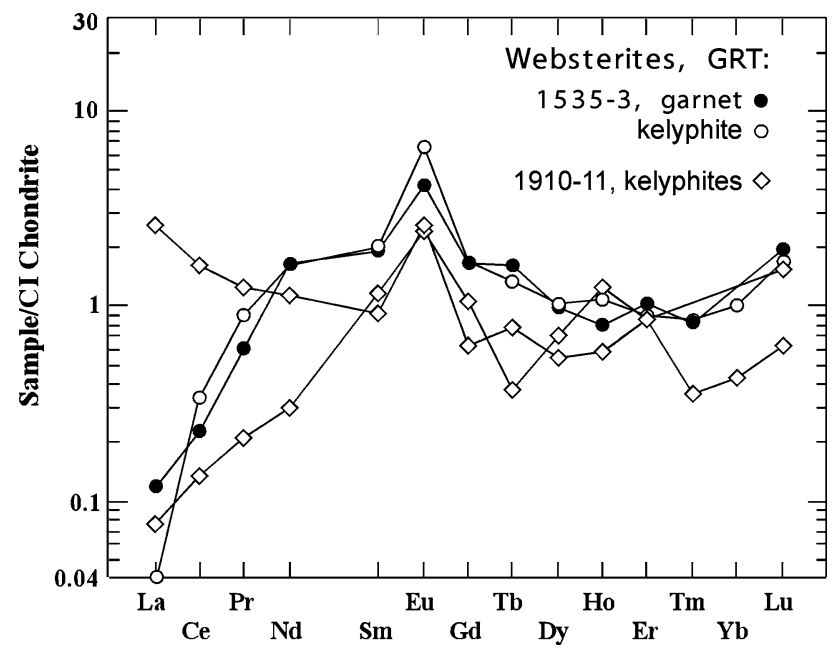

Fig. 7 Chondrite-normalized rare earth element patterns of garnet and kelyphites after garnet from the websterite xenoliths. Normalization values are from Sun and McDonough (1989)

by a moderate fractionation of HREE over LREE and by a positive Eu anomaly. Kelyphite was also analyzed for trace elements. Although major element concentrations hardly differ between garnet and adjacent kelyphite, trace elements in kelyphite show a considerable scatter (cf. garnet and two kelyphites in websterite 1910-11, Table 5). Some kelyphite areas have trace element abundances that are similar to those observed in garnet relicts, whereas others are strongly enriched in incompatible elements (Fig. 7).

\section{Whole-rock major and trace element composition}

The major and trace element compositions of the studied xenoliths are given in Table 6 . The rocks are basic, with $\mathrm{SiO}_{2}$ ranging from 44.9 to $50.2 \mathrm{wt} . \%$ and $\mathrm{MgO}$ ranging from 21.3 to $6.1 \mathrm{wt} . \%$. Their $\mathrm{Mg \# s}$ calculated on the basis of divalent iron are high (69.4-80.6). They are relatively rich in calcium and very rich in aluminum (15.5-24.6 wt. $\left.\% \quad \mathrm{Al}_{2} \mathrm{O}_{3}\right)$. Alkalies are Na-dominated. The C.I.P.W. normative compositions of the studied xenoliths are given in Table 7. They correspond to gabbroic and troctolitic protoliths.

The abundances of $\mathrm{Ni}$ and $\mathrm{Co}$ are remarkably high and vary between 209-1,061 and 113-238 $\mu \mathrm{g} / \mathrm{g}$, respectively. The Sr content reaches $872 \mu \mathrm{g} / \mathrm{g}$ and is often accompanied by high concentrations of $\mathrm{Ba}$ (up to $1,155 \mu \mathrm{g} / \mathrm{g})$. The contents of $\mathrm{Ti}$ and $\mathrm{Nb}$ are low $(<360$ and $<4.1 \mu \mathrm{g} / \mathrm{g}$, respectively). All studied xenoliths have very low abundances of REE, including the LREE.
Strong correlations are observed between $\mathrm{MgO}$ and all major and some trace elements (Fig. 8). At the same time, other trace elements, especially $\mathrm{Cr}, \mathrm{V}, \mathrm{Nb}$, $\mathrm{Zr}$, and REE, are not correlated with $\mathrm{MgO}$.

The chondrite-normalized REE patterns (Fig. 9a) show fractionation of LREE over HREE $\left[(\mathrm{La} / \mathrm{Yb})_{\mathrm{Cn}}\right.$ 3-33] and positive $\mathrm{Eu}$ anomalies, accentuated in granulites and much less pronounced in websterites. The abundances of the REE elements in granulites are generally lower than in websterites, with some granulite xenoliths being lower than CI chondrite with respect to $\mathrm{La}$ and $\mathrm{Ce}$ contents. The multi-element patterns of all studied xenoliths are similar and demonstrate a fractionation of LILE over HFSE and REE and pronounced positive anomalies of $\mathrm{Ba}, \mathrm{Sr}$, and $\mathrm{Eu}$ (Fig. 9b). In the granulites, less pronounced positive anomalies of $\mathrm{K}$ are also observed (Fig. 9b).

\section{Discussion}

Significance of the trace element patterns: late-stage metasomatic effects versus primary geochemical signature

Mineral and whole-rock trace element data reveal an apparent mismatch between the abundances of LILE, HFSE, and LREE in the xenoliths and their constituent minerals. For instance, websterite 1910-11 contains $1.5 \mu \mathrm{g} / \mathrm{g}$ of $\mathrm{Nb}$, yet the $\mathrm{Nb}$ content in its minerals does not exceed $0.25 \mu \mathrm{g} / \mathrm{g}$. Granulite $1904-9$ contains $3.6 \mu \mathrm{g} /$ $\mathrm{g}$ of $\mathrm{Zr}, 0.91 \mu \mathrm{g} / \mathrm{g}$ of $\mathrm{Nb}$, and $1.2 \mu \mathrm{g} / \mathrm{g}$ of $\mathrm{La}$, whereas the maximum contents of these elements in the minerals are $<0.32,<0.04$, and $<0.24 \mu \mathrm{g} / \mathrm{g}$, respectively (cf. Tables 5, 6). Among the rock-forming minerals of the xenoliths, only garnet, clinopyroxene and plagioclase can account for significant amounts of incompatible elements (see Table 5). Based on their modes and trace element compositions, we have calculated the expected bulk rock abundances for a selected set of incompatible elements, of which the concentrations are mostly above the detection limits (see Table 8). A comparison of the normalized REE and multi-element patterns of websterite xenoliths 1910-11 and 1535-3, obtained by LA-ICPMS on glass pills and calculated from modes, is given in Fig. 9c and d.

The results of these calculations confirm that although the concentrations of incompatible elements (particularly HFSE and REE) measured on glass pills are fairly low, the abundances expected from modes and mineral compositions are even lower. Xenoliths 1910-11, 1904-7, and 1904-1 are up to ten times richer in $\mathrm{Zr}, \mathrm{Nb}, \mathrm{La}$, and $\mathrm{Ce}$ than expected from their modal 
Table 6 Major-element (in wt.\% oxides) and trace-element (in $\mu \mathrm{g} / \mathrm{g}$ ) composition of websterite and granulite whole rock samples

\begin{tabular}{|c|c|c|c|c|c|c|c|}
\hline & Websterites & & $\mathrm{Mg}-\mathrm{Al}$ granu & & $\mathrm{Ca}-\mathrm{Al}$ granul & & \\
\hline & $1535-3$ & $1910-11$ & $1904-3$ & 1904-7 & $1906-2$ & $1904-9$ & $1904-1$ \\
\hline $\mathrm{SiO}_{2}$ & $45.98(0.36)$ & $44.94(0.53)$ & $46.51(0.96)$ & $47.65(0.85)$ & $46.39(0.60)$ & $50.18(0.63)$ & $49.66(0.91)$ \\
\hline $\mathrm{TiO}_{2}$ & $0.04(0.01)$ & $0.06(0.02)$ & $0.01(0.01)$ & $0.01(0.01)$ & $0.01(0.01)$ & $0.05(0.01)$ & $0.01(0.01)$ \\
\hline $\mathrm{Al}_{2} \mathrm{O}_{3}$ & $15.51(0.05)$ & $16.55(0.34)$ & $18.09(1.00)$ & $23.20(0.50)$ & $20.34(0.63)$ & $23.58(0.66)$ & $24.59(1.03)$ \\
\hline $\mathrm{FeO}_{\mathrm{t}}$ & $9.09(0.19)$ & $9.88(0.16)$ & $9.27(0.38)$ & $5.39(0.33)$ & $9.39(0.25)$ & $4.57(0.27)$ & $4.76(0.19)$ \\
\hline $\mathrm{MnO}$ & $0.11(0.04)$ & $0.13(0.03)$ & $0.11(0.03)$ & $0.08(0.02)$ & $0.11(0.02)$ & $0.06(0.03)$ & $0.06(0.02)$ \\
\hline $\mathrm{MgO}$ & $21.25(0.08)$ & $19.76(0.18)$ & $16.01(0.20)$ & $9.61(0.29)$ & $12.25(0.17)$ & $6.34(0.17)$ & $6.06(0.14)$ \\
\hline $\mathrm{CaO}$ & $7.01(0.08)$ & $7.69(0.12)$ & $8.12(0.23)$ & $10.32(0.16)$ & $8.59(0.13)$ & $10.68(0.15)$ & $10.11(0.12)$ \\
\hline $\mathrm{Na}_{2} \mathrm{O}$ & $0.65(0.03)$ & $0.55(0.03)$ & $1.74(0.08)$ & $2.82(0.12)$ & $2.37(0.05)$ & $3.55(0.11)$ & $3.72(0.12)$ \\
\hline $\mathrm{K}_{2} \mathrm{O}$ & $0.03(0.01)$ & $0.03(0.01)$ & $0.10(0.01)$ & $0.19(0.02)$ & $0.10(0.01)$ & $0.25(0.01)$ & $0.20(0.02)$ \\
\hline L.O.I. & 0.16 & 0.37 & 0.11 & 0.41 & 0.12 & 0.43 & 0.28 \\
\hline Total & 99.83 & 99.96 & 100.07 & 99.68 & 99.67 & 99.69 & 99.45 \\
\hline Mg\# & 80.64 & 78.09 & 75.48 & 76.06 & 69.93 & 71.2 & 69.41 \\
\hline XRF & & & & & & & \\
\hline $\mathrm{P}_{2} \mathrm{O}_{5}$ & 0.03 & 0.02 & 0.02 & 0.06 & 0.01 & 0.05 & 0.03 \\
\hline $\mathrm{Cr}$ & 331 & 156 & 87 & 65 & 919 & 238 & 102 \\
\hline $\mathrm{Ni}$ & 1,061 & 812 & 445 & 367 & 374 & 209 & 271 \\
\hline $\mathrm{Cu}$ & 28 & 10 & $<2$ & $<2$ & $<2$ & $<2$ & $<2$ \\
\hline $\mathrm{Sr}$ & 138 & 73 & 357 & 872 & 332 & 733 & 657 \\
\hline $\mathrm{Ba}$ & 82 & 138 & 102 & 627 & 60 & 1,155 & 955 \\
\hline LA-IC & & & & & & & \\
\hline $\mathrm{TiO}_{2}$ & $0.041(0.001)$ & $0.060(0.001)$ & $0.005(0.001)$ & $0.019(0.001)$ & $0.013(0.001)$ & $0.048(0.002)$ & $0.004(0.001)$ \\
\hline $\mathrm{MnO}$ & $0.119(0.003)$ & $0.131(0.002)$ & $0.115(0.006)$ & $0.072(0.002)$ & $0.102(0.002)$ & $0.063(0.002)$ & $0.053(0.002)$ \\
\hline $\mathrm{K}_{2} \mathrm{O}$ & $0.036(0.003)$ & $0.037(0.001)$ & $0.098(0.004)$ & $0.25(0.02)$ & $0.117(0.004)$ & $0.30(0.01)$ & $0.227(0.009)$ \\
\hline $\mathrm{P}_{2} \mathrm{O}_{5}$ & $0.021(0.004)$ & $0.013(0.001)$ & $0.010(0.001)$ & $0.039(0.003)$ & $0.010(0.001)$ & $0.033(0.003)$ & $0.020(0.002)$ \\
\hline $\mathrm{Li}$ & $1.21(0.07)$ & $1.4(0.2)$ & $1.5(0.2)$ & $1.0(0.1)$ & $2.6(0.2)$ & $4.1(0.3)$ & $1.7(0.2)$ \\
\hline $\mathrm{Cr}$ & $334(9)$ & $167(1)$ & $84(5)$ & $62(6)$ & $948(67)$ & $261(14)$ & 108 (12) \\
\hline Co & 188 (19) & $238(9)$ & $225(9)$ & $155(3)$ & $222(6)$ & $113(5)$ & $222(7)$ \\
\hline $\mathrm{Zn}$ & $55(27)$ & $68(13)$ & $57(7)$ & 35 (11) & $58(9)$ & $22(2)$ & $28(13)$ \\
\hline Sc & $8.6(0.9)$ & $6.6(0.3)$ & $2.5(0.1)$ & $1.8(0.1)$ & $4.3(0.1)$ & $6.0(0.3)$ & $1.4(1.0)$ \\
\hline $\mathrm{V}$ & $44(0.8)$ & $31(1)$ & $4.4(0.1)$ & $7.1(0.4)$ & 77 (2) & $37(1)$ & $5.8(0.8)$ \\
\hline $\mathrm{Rb}$ & $0.9(0.1)$ & $0.38(0.01)$ & $0.69(0.03)$ & $4.4(0.4)$ & $3.8(0.1)$ & $2.8(0.1)$ & $1.02(0.05)$ \\
\hline $\mathrm{Sr}$ & $146(5)$ & $74(1)$ & 344 (7) & $855(32)$ & 313 (14) & $718(12)$ & $651(8)$ \\
\hline $\mathrm{Y}$ & $0.9(0.1)$ & $1.1(0.1)$ & $0.04(0.01)$ & $0.44(0.02)$ & $0.06(0.01)$ & $0.72(0.02)$ & $0.13(0.03)$ \\
\hline $\mathrm{Zr}$ & $12.8(0.6)$ & $3.8(0.2)$ & $0.1(0.1)$ & $3.7(0.1)$ & $0.7(0.2)$ & $3.56(0.08)$ & $1.1(0.9)$ \\
\hline
\end{tabular}

$<$ values represent analyses below the limit of detection. $1 \sigma$ standard deviations for major $(n=12)$ and trace $(n=4-5)$ elements are given in parentheses

Table 7 The C.I.P.W. normative composition of the studied websterite and granulite xenoliths

\begin{tabular}{|c|c|c|c|c|c|c|c|}
\hline & \multicolumn{2}{|c|}{ Websterites } & \multicolumn{2}{|c|}{$\mathrm{Mg}-\mathrm{Al}$ granulites } & \multicolumn{3}{|c|}{$\mathrm{Ca}-\mathrm{Al}$ granulites } \\
\hline & $1535-3$ & $1910-11$ & $1904-3$ & $1904-7$ & $1906-2$ & $1904-9$ & $1904-1$ \\
\hline Orthose & 0.18 & 0.18 & 0.59 & 1.13 & 0.59 & 1.49 & 1.19 \\
\hline Albite & 5.51 & 4.67 & 14.71 & 22.22 & 20.12 & 29.63 & 29.90 \\
\hline Anorthite & 34.73 & 38.21 & 40.20 & 50.36 & 42.77 & 47.94 & 50.15 \\
\hline Corundum & 1.71 & 1.66 & 0.37 & no & 0.71 & no & no \\
\hline Nepheline & no & no & no & 0.96 & no & 0.31 & 0.97 \\
\hline Diopside (Wo) & no & no & no & 0.36 & no & 2.15 & 0.11 \\
\hline Diopside (En) & no & no & no & 0.24 & no & 1.32 & 0.07 \\
\hline Diopside (Fs) & no & no & no & 0.10 & no & 0.70 & 0.04 \\
\hline Hypersthene (En) & 19.93 & 16.30 & 6.95 & no & 1.69 & no & no \\
\hline Hypersthene (Fs) & 6.30 & 6.02 & 2.98 & no & 0.96 & no & no \\
\hline Olivine (Fo) & 23.35 & 23.31 & 23.16 & 16.77 & 20.35 & 10.25 & 10.64 \\
\hline Olivine (Fa) & 8.15 & 9.51 & 10.98 & 7.71 & 12.77 & 6.00 & 6.84 \\
\hline Ilmenite & 0.08 & 0.11 & 0.02 & 0.02 & 0.02 & 0.10 & 0.02 \\
\hline Apatite & 0.07 & 0.04 & 0.04 & 0.13 & 0.02 & 0.11 & 0.07 \\
\hline
\end{tabular}


Fig. 8 Variation diagrams for major and selected trace elements in the studied xenoliths
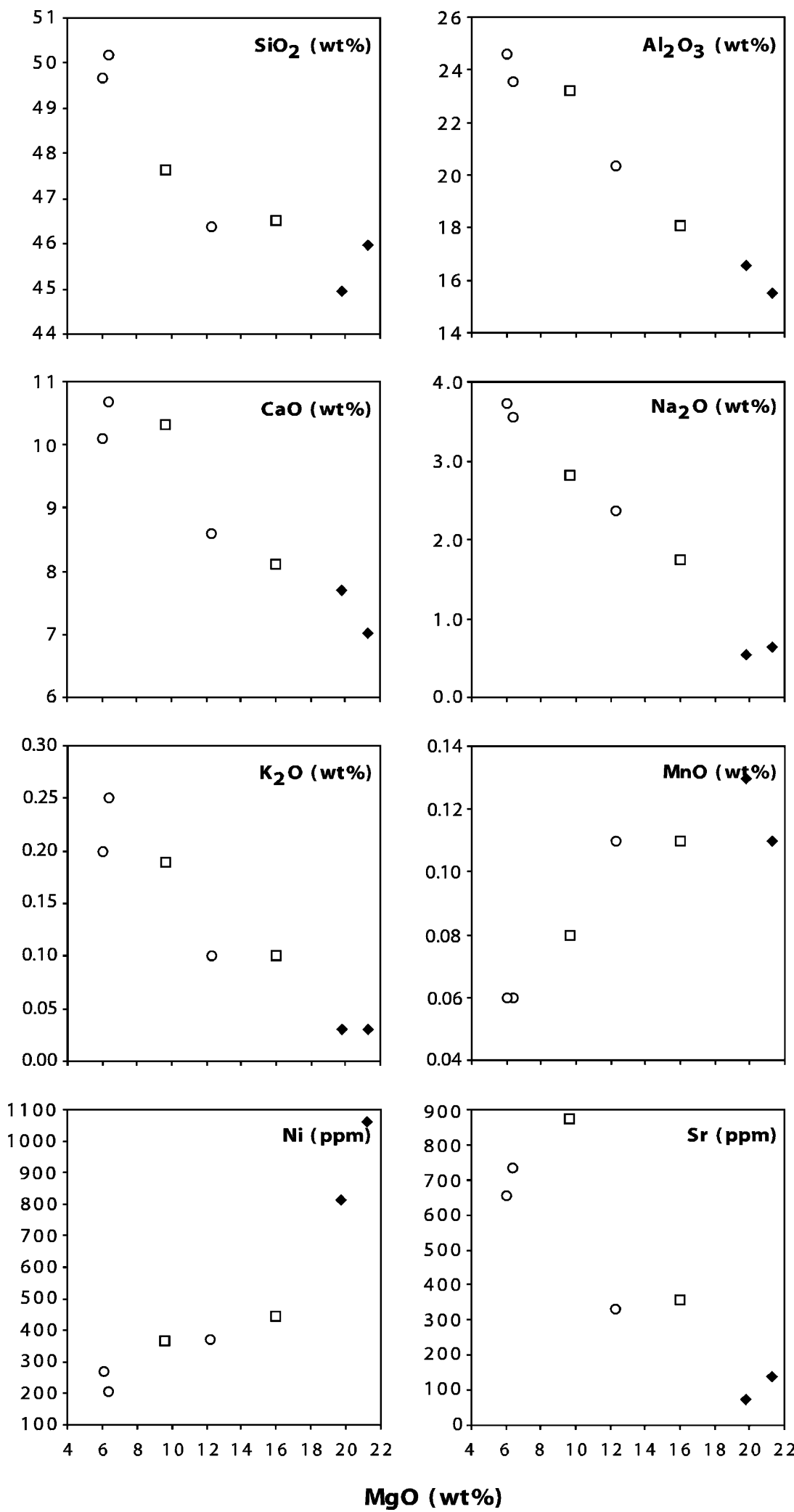

- ol websterites $\square$ Mg-Al granulites $\circ$ Ca-Al granulites 

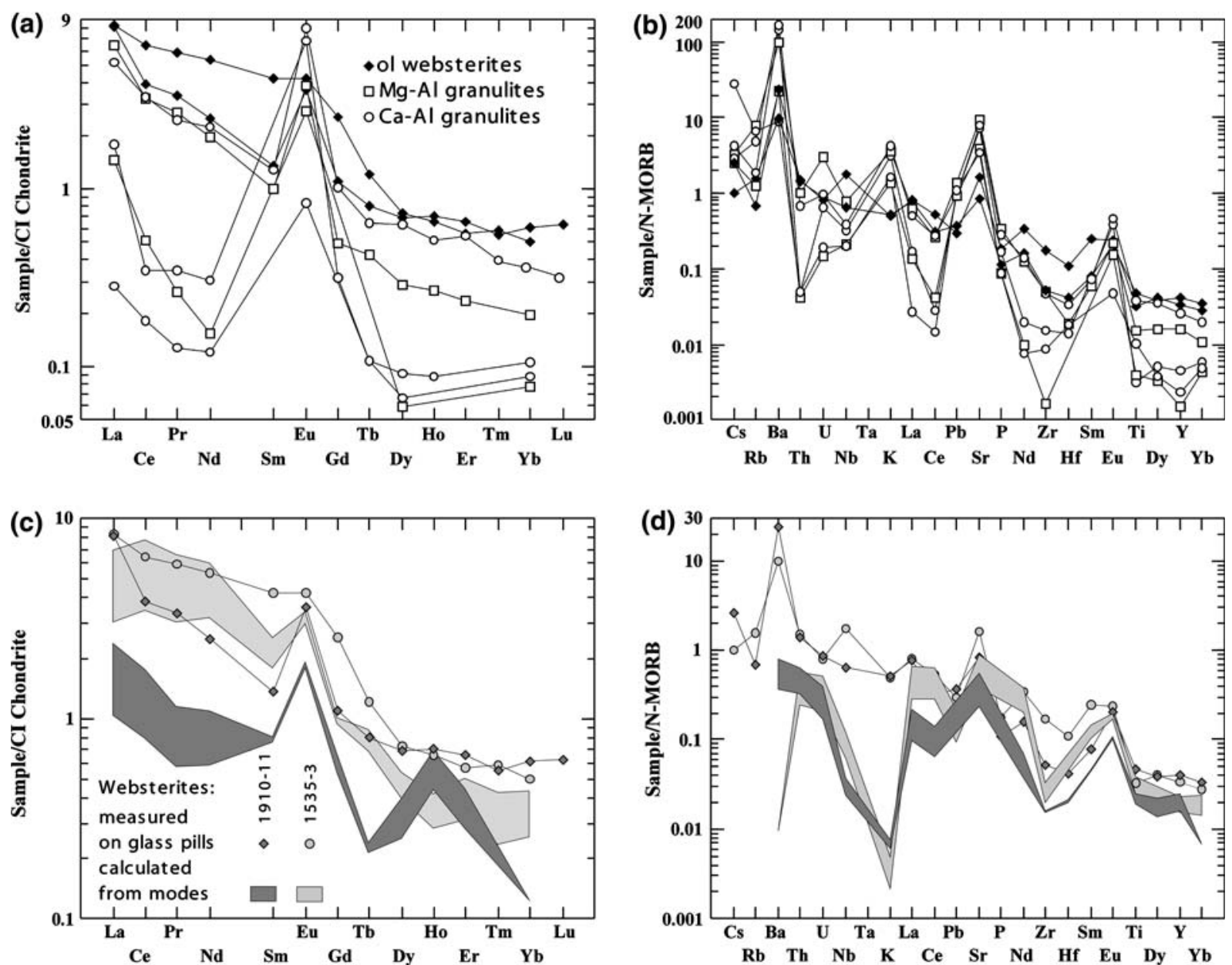

Fig. 9 Normalized bulk rock REE patterns (a) and multielement patterns (b) of the studied xenoliths. Comparative plots showing REE (c) and multi-element patterns (d) of websterite xenoliths obtained by LA-ICPMS on glass pills (filled diamonds and circles) and calculated from modal abundances and trace

element compositions of garnet and clinopyroxene (error $\pm 10 \%$ ). Granulites are not plotted, since many elements in their minerals are below the detection limits. Normalization values are from Sun and McDonough (1989)

Table 8 Selected whole rock trace element abundances in the studied xenoliths obtained by calculations based on mineral modes and mineral compositions

\begin{tabular}{|c|c|c|c|c|c|}
\hline $\begin{array}{l}1535-3 \\
25 \% \text { cpx } \\
40 \% \text { grt }\end{array}$ & $\begin{array}{l}1910-11 \\
25 \% \text { cpx } \\
45 \% \text { grt }\end{array}$ & $\begin{array}{l}1904-3 \\
7 \% \text { pl } \\
30 \% \text { cpx } \\
20 \% \text { grt }\end{array}$ & $\begin{array}{l}1904-7 \\
25 \% \mathrm{pl} \\
20 \% \mathrm{cpx} \\
20 \% \text { grt }\end{array}$ & $\begin{array}{l}1904-9 \\
45 \% \mathrm{pl} \\
30 \% \mathrm{cpx} \\
10 \% \text { grt }\end{array}$ & $\begin{array}{l}1904-1 \\
50 \% \mathrm{pl} \\
25 \% \mathrm{cpx} \\
10 \% \text { grt }\end{array}$ \\
\hline 0.0003 & 0.0005 & 0.103 & 0.097 & 0.102 & 0.248 \\
\hline 0.041 & 0.028 & 0.003 & 0.008 & 0.003 & 0.017 \\
\hline 57 & 36 & 247 & 363 & 356 & 379 \\
\hline 2.0 & 1.2 & $<0.082$ & $<0.16$ & 0.060 & $<0.31$ \\
\hline 0.21 & 0.073 & $<0.035$ & $<0.13$ & $<0.008$ & $<0.14$ \\
\hline 0.061 & 3.7 & 34 & 46 & 66 & 105 \\
\hline 1.2 & 0.40 & 0.11 & 0.20 & 0.15 & 0.30 \\
\hline 3.5 & 0.79 & 0.15 & 0.19 & 0.12 & 0.32 \\
\hline 0.46 & 0.082 & $<0.030$ & $<0.08$ & 0.014 & $<0.059$ \\
\hline 0.19 & 0.11 & $<0.13$ & 0.15 & 0.098 & $<0.21$ \\
\hline 0.047 & $<0.057$ & 0.14 & 0.30 & 0.19 & 0.44 \\
\hline
\end{tabular}

Orthopyroxene, spinel, corundum, sillmanite, and other minerals with low concentrations of incompatible elements are not included because of textural complexity of the studied rocks that hampers the calculation of mineral modes. For clinopyroxene, plagioclase and garnet (for some samples, kelyphite after garnet), averages from several laser LA-ICPMS analyses are used 
compositions and trace element abundances in garnet, clinopyroxene and plagioclase (cf. Tables 6, 8). The presence of accessory phases such as rutile, titanite, zircon or REE-epidote appears unlikely due to careful documentation of all specimens on the SEM and because of very low bulk rock abundances of the elements in question. We, therefore, assign the observed mismatch to the infiltration of fluids/melts shortly prior to or during transport of the xenoliths to the Earth's surface.

In the studied xenoliths, there is no evidence of modal metasomatism related to host magmatism. However, there is evidence of late-stage heating and reaction with fluids/melts in some websterite xenoliths, such as zoning patterns of outermost pyroxene rims (Altherr et al. 2006, submitted) and replacement of garnet by kelyphite (see above). LA-ICPMS analyses of kelyphite clearly show that its composition varies but that it may be enriched in HFSE, LREE, and LILE (Table 5, Fig. 7). The basanites of the Chyulu Hills generally show very high abundances of these elements (Späth et al. 2001). Late addition of these elements by metasomatism related to host magmatism could also account for the observed lack of correlation between $\mathrm{MgO}$ and $\mathrm{Nb}, \mathrm{Zr}$, and LREE. We believe, therefore, that for most specimens the abundances of the LREE and HFSE elements, remarkably low in general and therefore especially sensitive to late-stage alteration, may have been significantly modified via the interaction with the host basanitic magma.

On the other hand, the behavior of the LILE is better accounted for by the involvement of (a) LILErich phase(s). In websterite xenoliths, a dramatic difference between the contents of $\mathrm{K}$ and Ba measured on glass pills and calculated from the modes and trace element composition of garnet and clinopyroxene is observed (cf. Tables 6, 8), with the mineral-based values being much lower. Sr demonstrates a similar although less pronounced tendency. In specimen 15353 , despite the fact that the measured and calculated abundances of $\mathrm{La}$ and $\mathrm{Ce}$ are well matched (rather an exception than a rule), the $\mathrm{K}$ and $\mathrm{Ba}$ contents obtained by direct measurements (Table 6) are three orders of magnitude higher than those based on the compositions of garnet and clinopyroxene (Table 8). In granulites, in spite of plagioclase accounting for a significant general enrichment in the LILE, the mineral-based abundances of $\mathrm{Ba}$ and $\mathrm{Sr}$ are also substantially lower. At the same time, $\mathrm{K}$ and $\mathrm{Sr}$ are well correlated with $\mathrm{MgO}$ over the entire set of the studied xenoliths (Fig. 8). Barium, except for one specimen, also shows a good correlation with $\mathrm{MgO}$ (not plotted). An inclusion of potassium feldspar armored in clino- pyroxene and apparently cogenetic with it was found in websterite 1535-3. In granulite 1904-7, inclusions of celsian in plagioclase were observed. In both latter cases, no qualitative analyses were made due to small size of the inclusions. Accessory inclusions of K-feldspar in early pyroxene and garnet are also reported from other websterite xenoliths of the Chyulu Hills (Altherr et al. 2006, submitted). Therefore, the LILE contents, which are two to three orders of magnitude higher than REE and HFSE, may have undergone minor changes during late-stage metasomatism related to host magmatism, but seem to be largely controlled by the presence of minor amounts of (an) early K-, Ba-, Sr-rich phase(s) owing to the initial LILE enrichment of the protoliths.

\section{Major and trace element constraints} on the protoliths

For whole rock samples, the good correlation between $\mathrm{MgO}$ and other oxides (Fig. 8) leads to the conclusion that the suite of investigated xenoliths is meta-igneous and can be considered as a sequence of magmatic fractionation. The overall high bulk rock Mg\#s (80.6 69.4) suggest that not only websteritic but also granulitic xenoliths represent cumulates rather than crystallized melts. Positive Eu anomalies are consistent with a cumulate nature of the rocks. The Eu anomalies in whole rock samples generally match those observed in minerals (Fig. 5). Accentuated positive Eu (and Sr) anomalies in granulites suggest massive fractional crystallization of plagioclase (see Bindeman et al. 1998). Extreme fractionation of $\mathrm{Eu}$ in granulitic clinopyroxene (Fig. 5b, c) points to subsolidus crystallization via metamorphic reactions involving plagioclase, in good agreement with petrographic data (Ulianov and Kalt 2006). In websterites, Eu anomalies are less well expressed. They are nevertheless confirmed by the elevated abundances of $\mathrm{Eu}$ in garnet and clinopyroxene (Fig. 5a). This suggests the involvement of at least some plagioclase during fractional crystallization of the protolith, with subsequent replacement by mafic phases at subsolidus conditions. Moreover, high abundances of $\mathrm{Ni}$ and remarkably low $\mathrm{Cr}$ and $\mathrm{Ti}$ contents in bulk rock and minerals of all samples suggest that olivine was also important during the course of igneous crystallization, i.e., the original protoliths were close to gabbro (websterites) or troctolite (granulites). In the granulite xenoliths, the troctolitic assemblage (plagioclase + olivine) accounts for $>89.6 \%$ of the normative C.I.P.W. composition (Table 7).

In the whole rock trace element patterns of the studied xenoliths, some of the LREE fractionation has 
been interpreted to represent metasomatic additions (see previous section). Out of the seven analyzed specimens only one can be considered virtually free of the late-stage overprints ( $\mathrm{Ca}-\mathrm{Al}$ granulite 1906-2). It is characterized by extremely low abundances of REE and a low degree of their fractionation (Fig. 9a, lowermost pattern). The $(\mathrm{La} / \mathrm{Yb})_{\mathrm{Cn}}$ ratio of specimen 1906-2 is 3.4. Assuming that plagioclase carries the major part of the REE, and applying published partition coefficients for plagioclase (e.g. Dunn and Sen 1994) to the whole-rock composition of this specimen, yields a $(\mathrm{La} / \mathrm{Yb})_{\mathrm{Cn}}$ ratio of $\sim 20-60$, the values of ca. 20 40 being more consistent with most of the available partition coefficients (see Dunn and Sen 1994; Bindeman et al. 1998 and references therein). These values constrain the upper limit of the possible range of fractionation of LREE over HREE in the parental magma.

Several lines of evidence exclude the possibility that the xenoliths are cumulates of intraplate alkaline magmatism. As a rule, such cumulates are rich in clinopyroxene (and/or amphibole) and show elevated abundances of HFSE (e.g. Nimis and Vannucci 1995; Dobosi and Jenner 1999; Downes et al. 2001). Intraplate alkaline rocks, and in particular those erupted in quaternary times in the Chyulu Hills, are strongly enriched in HFSE (Späth et al. 2001). $\mathrm{TiO}_{2}$ contents may be up to 8 wt.\% (R. Altherr, unpublished data). Rare cognate cumulates in basanites of the Chyulu Hills are clinopyroxene-dominated and non-metamorphic. The studied xenoliths are strongly depleted in HFSE. They represent metamorphic rocks. Contrary to cumulates from alkaline volcanics, their protoliths correspond to gabbro and troctolite.

The studied xenoliths could be related to intraplate tholeiite, MORB or arc magmatism. Major and trace element compositions of mafic cumulates in arc settings are variable in terms of concentration levels and fractionation patterns. Nevertheless, most arc cumulates are characterized by fairly low REE contents, by a low to moderate fractionation of LREE over HREE, low HFSE and positive $\mathrm{Sr}$ and $\mathrm{Ba}$ anomalies (e.g. Himmelburg and Loney 1995; Cesare et al. 2002; Spandler et al. 2003; Claeson and Meurer 2004). Tholeiitic cumulates related to MORB or continental intraplate magmatism may have similar features such as low concentration levels of most incompatible elements and positive $\mathrm{Ba}$ and $\mathrm{Sr}$ anomalies. However, such cumulates, MORB-related cumulates in particular, are often characterized by flat REE patterns or depletion in LREE (e.g. Kornprobst et al. 1990; Benoit et al. 1996; Morishita et al. 2003), whereas the analyzed xenoliths show a fractionation of LREE over
HREE. At the same time, the LREE enrichment in the xenoliths seems (at least partly) related to late-stage overprints (see previous section).

Nature and evolution of the igneous protoliths

In the $\mathrm{Mg}-\mathrm{Al}$ sapphirine-bearing granulites, some grains of orthopyroxene and spinel may (mineralogically) represent igneous relicts, although the actual composition of most of them is controlled by metamorphism (Ulianov and Kalt 2006). The former presence of olivine is clearly indicated by the abundance of coarse-grained symplectite aggregates of opx, cpx, and spl which were formed by the subsolidus reaction ol + $\mathrm{pl}=\mathrm{opx}+\mathrm{cpx}+\mathrm{spl}$ (Fig. 3b). The 'primary' assemblage deduced for the $\mathrm{Mg}-\mathrm{Al}$ sapphirine-bearing granulites from their textures is thus in agreement with the bulk rock major and trace element data that suggest a troctolitic protolith, possibly with some pyroxene (see previous section). In the $\mathrm{Ca}-\mathrm{Al}$ hibonite-bearing granulites, only hibonite may represent an igneous relict with (partially) preserved chemical characteristics (Ulianov et al. 2005). The actual chemical composition of other phases, as in the $\mathrm{Mg}-\mathrm{Al}$ granulites, is defined by metamorphism. In general, textures and bulk rock major and trace element characteristics of the $\mathrm{Ca}-\mathrm{Al}$ granulites also suggest a plagioclase-rich troctolitic protolith.

The $P-T$ path deduced for the granulite xenoliths is characterized by cooling and compression (Ulianov and Kalt 2006). It involves crystallization of pyroxene and subsequently of garnet. The highest temperature obtained on early opx I in $\mathrm{Mg}-\mathrm{Al}$ sapphirine-bearing granulites is 1,090 and $1,135^{\circ} \mathrm{C}$; for the last stage of equilibration, the estimates are between 510 and $780^{\circ} \mathrm{C}$. Some textures related to the formation of garnet at the expense of corundum can be best interpreted as reflecting compression (Ulianov and Kalt 2006). However, as there is no evidence for early kyanite in the samples, the entire $P-T$ evolution of the granulites seems to be limited to the sillimanite stability field.

The geological data suggest that the igneous protoliths of the studied granulite and websterite xenoliths may represent arc cumulates. The Mozambique belt, which represents the lithosphere beneath the Chyulu Hills, was the site of multiple subduction and accretion in Pan-African times, e.g., between 750 and $615 \mathrm{Ma}$ (e.g. Coolen et al. 1982; Kröner et al. 1987; Stern and Dawoud 1991; Muhongo and Lenoir 1994; Möller et al. 1998, 2000, Muhongo et al. 2001; Kröner et al. 2003), finally consuming the Mozambique Ocean by the collision of East and West Gondwana (e.g. Meert 2003). 
Between the Pan-African events and tertiary to recent rift formation, the Mozambique lithosphere was not subject to major overprints. Therefore, the igneous protoliths of the granulite and websterite xenoliths from the Chyulu Hills most likely crystallized in the context of Pan-African arc magmatism. The $P-T$ paths, textures and mineral zoning patterns of the granulites are in line with igneous emplacement in the crust and cooling from igneous temperatures accompanied or followed by compression. Provided that cooling and compression were constrained to the sillimanite stability field and given the slope and position of the sillimanite-kyanite phase boundary, the protoliths of the granulite xenoliths must have intruded at rather shallow depths $(<8$ kbar).

For the websterite xenoliths, there is an apparent contradiction between the textural-mineralogical data and results of $P-T$ calculations on the one hand and some trace element data on the other hand. Large grain size, exsolution lamellae of garnet, high $\mathrm{Al}$ contents in cores of opx Ia and cpx Ia and pyroxene zoning patterns all indicate cooling from near-igneous temperatures at 1.9-2.0 GPa (Altherr et al. 2006, submitted). This may suggest that the investigated websterites are high-pressure cumulates, with early generation aluminous pyroxenes being igneous in origin. Igneous crystallization at deep levels would also be in line with the $\mathrm{Al}_{2} \mathrm{O}_{3}$ contents versus $\mathrm{Mg} \#$ of clinopyroxene that clearly follows the trend defined by high- $P$ igneous rocks (Fig. 10; e.g. Jan and Howie 1981; DeBari and Coleman 1989; Müntener et al. 2001) as opposed to low- $P$ igneous rocks (e.g. Beard and Day 1988; Topuz et al. 2004).

On the other hand, the positive $\mathrm{Eu}$ anomalies in bulk rock, clinopyroxene and garnet argue for plagioclase-bearing protoliths, whereas high Ni contents may point to early olivine. The stability of plagioclase and olivine in mafic arc magmas as a function of pressure, $\mathrm{H}_{2} \mathrm{O}$ and oxygen fugacity has been explored in a number of experimental studies (e.g. Johnston 1986; Bartels et al. 1991; Draper and Johnston 1992; Sisson and Grove, 1993; Müntener et al. 2001; Grove et al. 2003). In anhydrous systems, plagioclase (and olivine) stability as a liquidus phase is usually limited to pressures below 1.0-1.2 GPa. Only in some dry high-alumina basaltic systems plagioclase was found as a liquidus phase up to $1.7 \mathrm{GPa}$ (Johnston 1986). The effect of $\mathrm{H}_{2} \mathrm{O}$ is to suppress plagioclase crystallization and to expand the olivine stability field at low and medium pressures. It is very unlikely that the positive $\mathrm{Eu}$ anomalies observed in the websterites are due to early plagioclase crystallization at pressures of approximately $2.0 \mathrm{GPa}$.
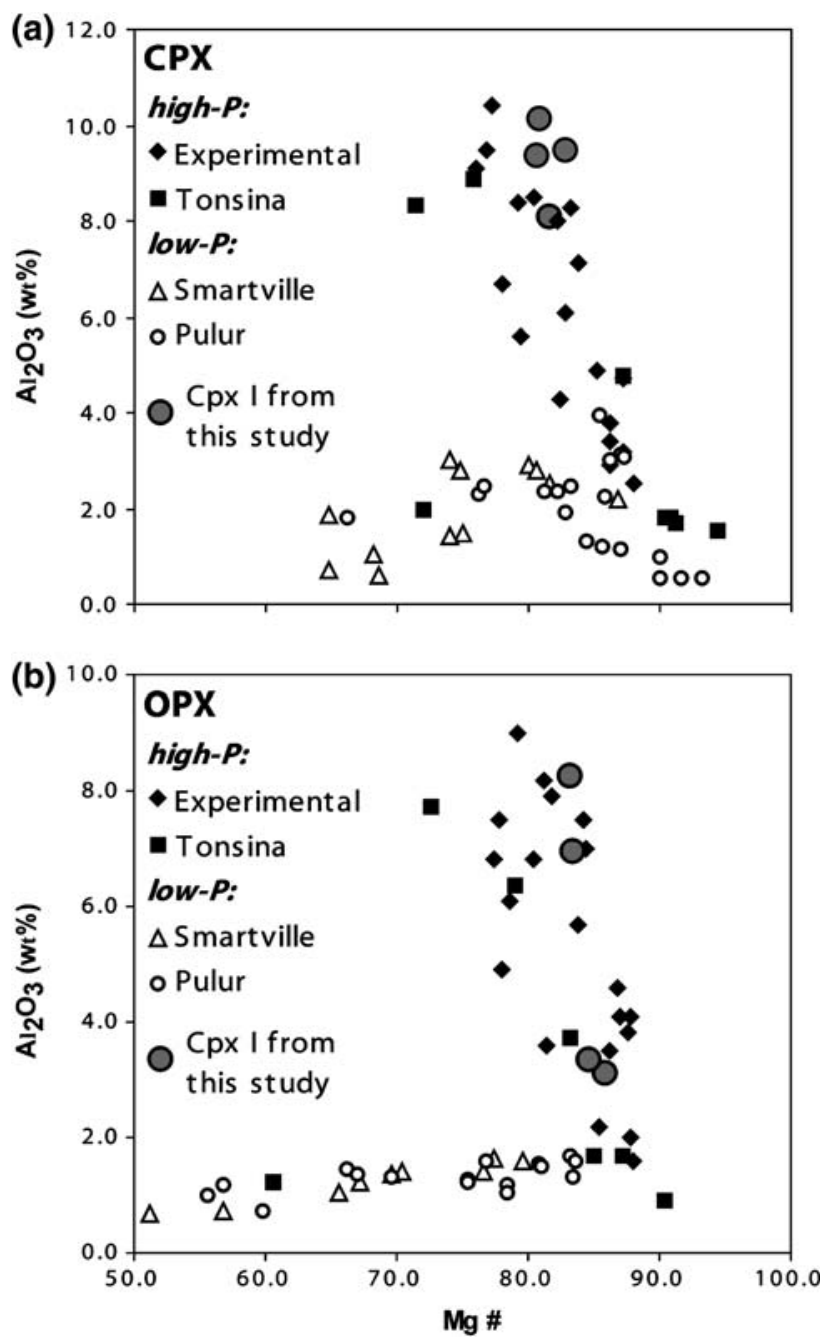

Fig. 10 a $\mathrm{Al}_{2} \mathrm{O}_{3}$ contents versus $X_{\mathrm{Mg}}$ in clinopyroxene of the websterite xenoliths from the Chyulu Hills. b $\mathrm{Al}_{2} \mathrm{O}_{3}$ contents versus $X_{\mathrm{Mg}}$ in orthopyroxene of the websterite xenoliths from the Chyulu Hills. Also shown are data from experimental igneous pyroxenites at $1.2 \mathrm{GPa}$ (Müntener et al. 2001) and from arc cumulates: Tonsina (DeBari and Coleman 1989), Smartville (Beard and Day 1988), and Pulur (Topuz et al. 2004)

Thus, the igneous protoliths of the websterite xenoliths appear to represent crustal plagioclase-bearing cumulates corresponding to gabbro or gabbrotroctolites. Transport of such protoliths to mantle depths results in their transformation to websterite by two reactions: (1) ol $+\mathrm{pl}=\mathrm{opx}+\mathrm{cpx}+\mathrm{spl}$ and (2) opx $+\mathrm{cpx}+\mathrm{spl}=\mathrm{grt}+\mathrm{ol}$. Both of these reactions appear quite plausible given the petrography of the rocks and $P-T$ estimates of their equilibration. Very high (nearigneous) peak temperatures recorded in aluminous pyroxenes from the websterites may suggest a hightemperature environment during transport.

Subduction could in principle be a viable process for transporting the websterite protoliths to mantle depth. 
This process has been invoked for pyroxenites of orogenic mafic-ultramafic complexes from several localities (e.g. Beni Bousera: Kornprobst et al. 1990; Ronda: Morishita et al. 2003; Horoman: Morishita et al. 2004). All these rocks are tholeiitic and represent former oceanic crust metamorphosed during subduction. In our case, however, the 'classical' subduction setting with high $P / T$ gradients for the rocks carried to depth seems unlikely. First, textures and mineral compositions/zoning patterns suggest that at least the websterites were hot at depth, whereas there is no evidence for earlier cooling. Second, almost no eclogites are found as xenoliths in the Chyulu Hills, contrary to what would be expected in a classical subduction scenario.

Another, more viable model to account for the observed textures, mineral compositions and bulk rock chemistry of the investigated xenoliths is a scenario where granulites and websterites represent crustal plagioclase-bearing mafic cumulates carried to depth (granulites to a lesser degree) due to convective instability of dense hot ultramafic-mafic lower crust, which is possible in regions of elevated heat flow such as arcs (Jull and Kelemen 2001). This process is currently being observed beneath the Sierra Nevada. There, xenolith (e.g. Ducea and Saleeby 1996; Ducea 2001) and seismic evidence (Boyd et al. 2004; Zandt et al. 2004) suggest that mafic lower crust is dragged into the mantle down to at least $70 \mathrm{~km}$. Parts of the Sierra Nevada have lost about half of its original crust due to convective removal of dense garnet-bearing lowermost crustal rocks (e.g. Ducea and Saleeby 1996; Lee et al. 2001). In this context and in accord with the geological setting of the Chyulu Hills, the protoliths of the studied websterite and granulite xenoliths could represent part of a dense Pan-African lithospheric arc root that began to founder into the mantle when subduction ceased after closure of the Mozambique ocean.

\section{Concluding remark}

Major and trace element data on aluminous granulite xenoliths from the Chyulu Hills volcanic field, Kenya, suggest that these rocks were troctolitic cumulates almost completely recrystallized during subsolidus cooling and compression. In order to reconcile apparently contradictory features of the websterite xenoliths, e.g., high $P-T$ near-igneous major element composition of pyroxenes versus positive bulk rock and mineral $\mathrm{Eu}$ anomalies, it appears necessary to invoke a model of foundering of hot dense gabbroic crustal material into the mantle, possibly during the Pan-African.
Acknowledgments We would like to thank Rainer Altherr and Othmar Müntener for fruitful discussions and for help in improving the first version of this manuscript. We are grateful to Hilary Downes and to an anonymous reviewer for their constructive reviews that helped to improve the focus of the manuscript. Thanks also go to Hans-Peter Meyer and Edwin Gnos for assistance with electron microprobe analysis, to Vincent Serneels for providing XRF analyses and to HansMichael Seitz for preparing the glass pills. Permission and help for field sampling provided by the Office of the President, Kenya Wildlife Service, and the Kenya Agricultural Research Institute in Kiboko are gratefully acknowledged. This research was supported by the Swiss National Science Foundation grant 200021-100647/1.

\section{References}

Ai Y (1994) A revision of the garnet-clinopyroxene $\mathrm{Fe}^{2+}-\mathrm{Mg}$ exchange geothermometer. Contrib Mineral Petrol 115:467473

Al-Mishwat AT, Nasir SJ (2004) Composition of the lower crust of the Arabian plate: a xenolith perspective. Lithos $72: 45-72$

Baker BH, Williams LAJ, Miller JA, Fitch FJ (1971) Sequence and geochronology of the Kenya rift volcanics. Tectonophysics 11:191-215

Bartels KS, Kinzler RJ, Grove TL (1991) High pressure phase relations of primitive high-alumina basalts from Medicine Lake volcano, northern California. Contrib Mineral Petrol 108:253-270

Beard JS, Day HW (1988) Petrology and emplacement of reversely zoned gabbro-diorite plutons in the Smartville complex, Northern California. J Petrol 29:965-995

Benoit M, Polvé M, Ceuleneer G (1996) Trace element and isotopic characterization of mafic cumulates in a fossil mantle diapir (Oman ophiolite). Chem Geol 134:199-214

Bindeman IL, Davis AM, Drake MJ (1998) Ion microprobe study of plagioclase-basalt partition experiments at natural concentration levels of trace elements. Geochim Cosmochim Acta 62:1175-1193

Boyd OS, Craig HJ, Sheehan AF (2004) Foundering lithosphere imaged beneath the southern Sierra Nevada. Science 305:660-662

Brey GP, Köhler T (1990) Geothermobarometry in four-phase lherzolites II. New thermobarometers, and practical assessment of existing thermobarometers. J Petrol 31:1353-1378

Brey GP, Nickel KG, Kogarko L (1986) Garnet-pyroxene equilibria in the system $\mathrm{CaO}-\mathrm{MgO}-\mathrm{Al}_{2} \mathrm{O}_{3}-\mathrm{SiO}_{2}$ (CMAS): prospects for simplified (T-independent) lherzolite barometry and an eclogite barometer. Contrib Mineral Petrol 92:448-455

Cesare B, Rubatto D, Hermann J, Barzi L (2002) Evidence for late carboniferous subduction-type magmatism in maficultramafic cumulates of the SW Tauern window (Eastern Alps). Contrib Mineral Petrol 142:449-464

Claeson DT, Meurer WP (2004) Fractional crystallization of hydrous basaltic arc-type magmas and the formation of amphibole-bearing gabbroic cumulates. Contrib Mineral Petrol 147:288-304

Conrad WK, Kay RW (1984) Ultramafic and mafic inclusions from Adak island: crystallization history, and implications for the nature of primary magmas and crustal evolution in the Aleutian arc. J Petrol 25:88-125 
Coolen JJMMM, Priem HNA, Verdurmen EAT, Verschure RH (1982) Possible zircon U-Pb evidence for Pan-African granulite-facies metamorphism in the Mozambique belt of southern Tanzania. Precambrian Res 17:31-40

Dawson JB (1977) Sub-cratonic crust and upper mantle models based on xenolith suites in kimberlite and nephelinitic diatremes. J Geol Soc London 134:173-184

DeBari SM, Coleman RG (1989) Examination of the deep levels of an island arc: evidence from the Tonsina ultramafic-mafic assemblage, Tonsina, Alaska. J Geophys Res 94:4373-4391

DeBari SM, Mahlburg Kay S, Kay RW (1987) Ultramafic xenoliths from Adagdak volcano, Adak, Aleutian Islands, Alaska: deformed igneous cumulates from the $\mathrm{MOHO}$ of an island arc. J Geol 95:329-341

Dessai AG, Markwick A, Vaselli O, Downes H (2004) Granulite and pyroxenite xenoliths from the Deccan trap: insight into the nature and composition of the lower lithosphere beneath cratonic India. Lithos 78:263-290

Dobosi G, Jenner GA (1999) Petrologic implications of trace element variation in clinopyroxene megacrysts from the Nógrád volcanic province, north Hungary: a study by laser ablation microprobe-inductively coupled plasma-mass spectrometry. Lithos 46:731-749

Downes H, Upton BGJ, Handisyde E, Thirlwall MF (2001) Geochemistry of mafic and ultramafic xenoliths from Fidra (Southern Uplands, Scotland): implications for lithospheric processes in permo-carboniferous times. Lithos 58:105-124

Draper DS, Johnston AD (1992) Anhydrous PT phase relations of Aleutian high $\mathrm{MgO}$-basalt: an investigation of the role of olivine-liquid reaction in the generation of arc high-alumina basalts. Contrib Mineral Petrol 112:501-519

Ducea MN (2001) The California arc: thick granitic batholiths, eclogitic residues, lithospheric-scale thrusting, and magmatic flare-ups. GSA Today 11:4-10

Ducea MN, Saleeby JB (1996) Buoyancy sources for a large unrooted mountain range, the Sierra Nevada, California: Evidence from xenolith thermobarometry. J Geophys Res 101:8229-8244

Dunn T, Senn C (1994) Mineral/matrix partition coefficients for orthopyroxene, plagioclase and olivine in basaltic to andesitic systems: a combined analytical and experimental study. Geochim Cosmochim Acta 58:717-733

Embey-Isztin A, Downes H, Kempton PD (2003) Lower cerustal granulite xenoliths from the Pannonian Basin, Hungary. Part I: mineral chemistry, thermobarometry and petrology. Contrib Mineral Petrol 144:652-670

Grove TL, Elkins-Tanton LT, Parman SW, Chatterjee N, Müntener O, Gaetani GA (2003) Fractional crystallization and mantle-melting controls on calc-alkaline differentiation trends. Contrib Mineral Petrol 145:515-533

Günther D, Frischknecht R, Heinrich CA (1997) Capabilities of a $193 \mathrm{~nm}$ ArF excimer laser for LA-ICPMS micro analysis of geological materials. J Anal Atom Spectrom 12:939-944

Harley SL (1984) An experimental study of the partitioning of $\mathrm{Fe}$ and $\mathrm{Mg}$ between garnet and orthopyroxene. Contrib Mineral Petrol 86:359-373

Haug GH, Strecker MR (1995) Volcano-tectonic evolution of the Chyulu Hills and implication for the regional stress field in Kenya. Geology 23:165-168

Heinrich CA, Pettke T, Halter WE, Aigner-Torres M, Audétat A, Günther D, Hattendorf B, Bleiner D, Guillong M, Horn I (2003) Quantitative multi-element analysis of minerals, fluid and melt inclusions by laser-ablation inductively-coupledplasma mass-spectrometry. Geochim Cosmochim Acta 67:3473-3496
Henjes-Kunst F, Altherr R (1992) Metamorphic petrology of xenoliths from Kenya and Northern Tanzania and implications for geotherms and lithospheric structure. J Petrol 33:1125-1156

Hermann J, Müntener O, Günter D (2001) Differentiation of mafic magma in a continental crust-to-mantle transition zone. J Petrol 42:189-206

Himmelburg GR, Loney RA (1995) Characteristics and petrogenesis of Alaskan-type ultramafic-mafic intrusions, southeastern Alaska. US Geol Surv Prof Pap 1564

Jan MQ, Howie RA (1981) The mineralogy and geochemistry of the metamorphosed basic and ultrabasic rocks of the Jijal complex, Kohistan, NW Pakistan: J Petrol 22:85-126

Johnston AD (1986) Anhydrous P-T relations of near-primary high-alumina basalt from the South Sandwich Islands. Contrib Mineral Petrol 92:368-382

Jones AP, Smith JV, Hansen EC, Dawson JB (1983) Metamorphism, partial melting and K-metasomatism of garnetscapolite-kyanite granulite xenoliths from Lashaine, Tanzania. J Geol 91:143-165

Jull M, Kelemen PB (2001) On the conditions of lower crustal convective instability. J Geophys Res 106:6423-6446

Kempton PD, Downes H, Neymark LA, Wartho JA, Zartman RE, Sharkov EV (2001) Garnet granulite xenoliths from the Northern Baltic Shield-the underplated lower crust of a palaeoproterozoic large igneous province? J Petrol 42:731763

Kornprobst J, Piboule M, Roden M, Tabit A (1990) Corundumbearing garnet clinopyroxenites at Beni Bousera (Morocco): Original plagioclase-rich gabbros recrystallized at depth within the mantle? J Petrol 31:717-745

Kretz R (1983) Symbols for rock-forming minerals. Am Mineral 68:277-279

Krogh Ravna E (2000) The garnet-clinopyroxene Fe-Mg geothermometer: an updated calibration. J Metamorph Geol 18:211-219

Kröner A, Greiling R, Reischmann T, Hussein IM, Stern RJ, Dürr S, Krüger J, Zimmer M (1987). Pan-African crustal evolution in the Nubian segment of northeast Africa. In: Kröner A (ed) Proterozoic lithospheric evolution, geodynamic series, vol 17. American Geophysical Union, Washington, DC, pp 235-257

Kröner A, Muhongo S, Hegner E, Wingate MTD (2003) Single zircon geochronology and $\mathrm{Nd}$ isotopic systematics of Proterozoic high-grade rocks from the Mozambique belt of southern Tanzania (Masasi area): implications for Gondwana assembly. J Geol Soc London 160:745-758

Lee CT, Rudnick RL, Brimhall GH (2001) Deep lithospheric dynamics beneath the Sierra Nevada during the Mesozoic and Cenozoic as inferred from xenolith petrology. Geochem Geophys Geosys 2:2001GC000152

McGuire AV, Stern RJ (1993) Granulite xenoliths from western Saudi Arabia: the lower crust of the late Precambrian Arabian-Nubian Shield. Contrib Mineral Petrol 114:395408

Meert JG (2003) A synopsis of events related to the assembly of eastern Gondwana. Tectonophysics 362:1-40

Möller A, Mezger K, Schenk V (1998) Crustal age domains and the evolution of the continental crust in the Mozambique belt of Tanzania: combined $\mathrm{Sm}-\mathrm{Nd}, \mathrm{Rb}-\mathrm{Sr}$ and $\mathrm{Pb}-\mathrm{Pb}$ isotopic evidence. J Petrol 39:749-783

Möller A, Mezger K, Schenk V (2000) U-Pb dating of metamorphic minerals: Pan-African metamorphism and prolonged slow cooling of high pressure granulites in Tanzania, east Africa. Precambrian Res 104:123-146 
Morishita T, Arai S, Gervilla F, Green D (2003) Closed-system geochemical recycling of crustal materials in alpine-type peridotite. Geochim Cosmochim Acta 67:303-310

Morishita T, Arai S, Green D (2004) Possible non-melted remnants of subducted lithosphere: experimental and geochemical evidence from corundum-bearing mafic rocks in the horoman peridotite complex, Japan. J Petrol 45:235-252

Muhongo SM, Lenoir J-L (1994) Pan-African granulite facies metamorphism in the Mozambique belt of Tanzania: U-Pb zircon geochronology. J Geol Soc London 151:343-347

Muhongo SM, Kröner A, Nemchin AA (2001) Zircon ages from granulite facies rocks in the Mozambique belt of Tanzania and implications for Gondwana assembly. J Geol 109:171189

Müntener O, Kelemen PB, Grove TL (2001) The role of $\mathrm{H}_{2} \mathrm{O}$ during crystallization of primitive arc magmas under uppermost mantle conditions and genesis of igneous pyroxenites: an experimental study. Contrib Mineral Petrol 141:643-658

Nasir S (1995) Mafic lower crustal xenoliths from the northwestern part of the Arabian Plate. Eur J Mineral 7:217-230

Nimis P, Vannucci R (1995) An ion microprobe study of clinopyroxenes in websteritic and megacrystic xenoliths from Hyblean plateau (SE Sicily, Italy): constraints on HFSE/ $\mathrm{REE} / \mathrm{Sr}$ fractionation at mantle depth. Chem Geol 124:185197

Novak O, Prodehl C, Jacob AWB, Okoth W (1997a) Crustal structure of the southern flank of the Kenya rift deduced from wide-angle P-wave data. Tectonophysics 278:171-186

Novak O, Ritter JRR, Altherr R, Garasic V, Volker F, Kluge C, Kaspar T, Byrne GF, Sobolev SV, Fuchs K (1997b) An integrated model for the deep structure of the Chyulu Hills volcanic field, Kenya. Tectonophysics 278:187-209

Omenge JM, Okelo RE (1992) Geology of the Chyulu-Oloitokitok area. Kenya Mines and Geology Department, Nairobi, Report 112, 51pp

Pettke T, Halter WE, Webster JD, Aigner-Torres A, Heinrich CA (2004) Accurate quantification of melt inclusion chemistry by LA-ICPMS: A comparison with EMP and SIMS and advantages and possible limitations of these methods. Lithos 78:333-361

Ritter JRR, Kaspar T (1997) A tomography study of the Chyulu Hills, Kenya. Tectonophysics 278:149-169

Saggerson EP (1963) Geology of the Simba-Kibwezi area. Geological survey of Kenya, Report 58, 70pp

Sisson TW, Grove TL (1993) Experimental investigations of the role of $\mathrm{H}_{2} \mathrm{O}$ in calc-alkaline differentiation and subduction zone magmatism. Contrib Mineral Petrol 113:143-166

Spandler CJ, Arculus RJ, Eggins SM, Mavrogenes J, Price RC, Reay AJ (2003) Petrogenesis of the Greenhills complex,
Southland, New Zealand: magmatic differentiation and cumulate formation at the roots of a Permian island-arc volcano. Contrib Mineral Petrol 144:703-721

Späth A, Le Roex AP, Opiyo-Akech N (2001) Plume-lithosphere interaction and the origin of continental rift-related alkaline volcanism-the Chyulu Hills volcanic field, Southern Kenya. J Petrol 42:765-787

Stern RJ, Dawoud AS (1991) Late precambrian (740 Ma) charnockite, enderbite, and granite from Jebel Moya, Sudan: a link between the Mozambique belt and the Arabian-Nubian shield? J Geol 99:648-659

Sun SS, McDonough WF (1989) Chemical and isotopic systematics of oceanic basalts: implications for mantle composition and processes. In: Saunders AD, Norry MJ (eds) Magmatism in ocean basins. Geol Soc Spec Publ 42:313-345

Sutherland FL, Hollis JD, Birch WD, Pogson RE, Raynor LR (2004) Cumulate-rich xenolith suite in late Cenozoic basaltic eruptives, Hepburn Lagoon, Newlyn, in relation to western Victorian lithosphere. Aust J Earth Sci 51:319-337

Takazawa E, Frey EA, Shimizu N, Saal A, Obata M (1999) Polybaric petrogenesis of mafic layers in the Horoman peridotite complex, Japan. J Petrol 40:1827-1851

Topuz G, Altherr R, Schwarz WH, Meyer HP, Eyüboglu Y, Sen C (2004) Ultramafic-mafic intrusions of the Pulur region (NE Turkey): products of shallow-level differentiation and cumulate formation beneath a late Liassic continental arc. Lithos 72:183-207

Ulianov A, Kalt A (2006) Mg-Al sapphirine- and Ca-Al hibonite-bearing granulite xenoliths from the Chyulu Hills volcanic field, Kenya. J Petrol 47:901-927

Ulianov A, Kalt A, Pettke T (2005) Hibonite, Ca(Al, Cr, Ti, Si, $\left.\mathrm{Mg}, \mathrm{Fe}^{2+}\right)_{12} \mathrm{O}_{19}$, and its mineral assemblage in Ca-Al metaigneous granulite xenoliths from the Chyulu Hills volcanic field, Kenya. Eur J Mineral 17:357-366

Upton BGJ, Aspen P, Hinton RW (2001) Pyroxenite and granulite xenoliths from beneath the Scottish northern highlands Terrane: evidence for lower-crust/upper mantle relationships. Contrib Mineral Petrol 142:178-197

Weber MBI, Tarney J, Kempton PD, Kent RW (2002) Crustal make-up of the northern Andes: evidence based on deep crustal xenolith suites, Mercaderes, SW Colombia. Tectonophysics 345:49-82

Wells PRA (1977) Pyroxene thermometry in simple and complex systems. Contrib Mineral Petrol 62:129-139

Williams LAJ (1970) The volcanics of the Gregory rift valley, East Africa. Bulletin 34:439-465

Zandt G, Gilbert H, Owens TJ, Ducea M, Saleeby J, Jones CH (2004) Active foundering of a continental arc root beneath the southern Sierra Nevada in California. Nature 431:41-46 